\section{KALKINMA VE}

CEVVRESEL

\section{SEKTÖRLER}

\section{EKSENINDEN}

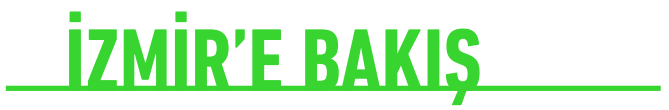

\section{Pınar Börü* \\ Meneviş Uzbay Pirili*}

Dünyada gezegenin sınırlarına vurgu yapan çalışmalar 1970 'li yıllardan itibaren yayınlanmaya başlamıştır. Son dönemde elde edilen bulgulara göre; özellikle 1950 'lerden sonra gezegenin sistemlerine ilişkin parametrelerde gerçekleşen olumsuz artışlar, büyük oranda insan faaliyetlerinden kaynaklanmaktadır. Günümüzde etkisi ģiderek daha çok hissedilen küresel iklim değişikliğinin bir sonucu olarak, yaşanan çeure felaketleri ve içinde bulunduğumuz pandemi de gerek gezegen için gerekse yaşamlarımız için kırılganlıklarımızı arttırmaktadır. Bu nedenle artık mevcut yaşam biçimlerimizle devam edemeyeceğimiz pek çok kesim tarafından kabul görmekte ve bir dönüşümün gerekliliģ̆i açıkça ortaya konulmaktadır. Bu dönüşümün çerçevesi sorunlu üretim ve tüketim örüntülerinin, sosyal sistemlerimizin sürdürülebilir ve kapsayıcı olması ile çizilmektedir. Bu nedenle özellikle ekonomik alanda bir dönüşümün; çeuresel ve sosyal alanlarda insan kaynaklı baskıları azaltmada ciddi bir etkisi olacaktır. Gerçekleştirilecek çeuresel analizlerle ekonominin bu alandaki potansiyelinin ortaya konulabilmesi ekonomik dönüşüm için büyük önem arz etmektedir. Bu çalışmada da sürdürülebilir kalkınma perspektifinden yola çıkılarak çeuresel sektörler açısından İzmir ilinin potansiyeli değerlendirilmektedir.

Anahtar Sözcükler: Sürdürülebilir Kalkınma,

Çeuresel Sektörler, Çeuresel İstihdam,

Kapsayıcı Yeşil Büyüme, İzmir

\section{Meltem}

İzmir Akdeniz Akademisi Derģisi/

Journal of the Izmir Mediterranean Academy

No. 9, Yaz/Summer 2021, 77-99, DOI 10.32325/iaad.2021.5

* Bağımsız Araştırmacı / Independent Researcher / ORCID iD https://orcid.org/0000-0001-9677-2686

** Yaşar Üniversitesi, Ekonomi Bölümü, Yarı Zamanlı Öğretim Üyesi / Yaşar University, Department of Economics, Part-time Instructor / ORCID iD https://orcid.org/0000-0001-6161-467X 


\section{Sustainable Development and Environmental Sectors Outlook in Izmir}

Studies focusing on the boundaries of the planet began to be published in the 1970s. According to recent findings, negative increases within systemic changes to the planet especially after the 1950s, are largely due to human activities. As a result of global climate change, the impact of which is increasingly felt today, the environmental disasters and the pandemic we are in also increase our vulnerability both for the planet and for our lives. For this reason, it is accepted by many that we can no longer continue with our existing ways of life, and this need for transformation is made apparent. The framework for this transformation is drawn by the fact that problematic production and consumption patterns, our social systems are more sustainable and inclusive. Especially with a transformation in the economic field; a serious impact can be made in reducing human-caused pressures in the environmental and social areas. The key to economic transformation is the economic potential in this area can be demonstrated by these environmental analysis. In this study, the potential of Izmir province will be evaluated from the point of view of environmental sectors based on the perspective of sustainable development.

\section{Keywords: Sustainable Development, Environmental Sectors, Environmental Employment, Inclusive Green Growth, Izmir}

Literatürde gezegenin sınırlarına yaptığı vurgu ile büyük ses getiren Roma Kulübü'nün 1972 yılında yayınladığı "Büyümenin Sınırları" raporu ${ }^{1}$ dünya çapında devam eden büyümenin sonuçlarını sistem analizi yaklaşımı ile değerlendirerek, doğal kaynaklardaki kısıtllığın bunların kullanımına dayalı ekonomik sistemdeki büyümeyi bir noktadan sonra sınırlayacağını ortaya koymuştur. 1987 yılına gelindiğinde ise sürdürülebilir kalkınma kavramı bugün bilinen anlamıla ilk kez Brundtland Raporu olarak da bilinen "Ortak Geleceğimiz" raporunda literatürdeki yerini almıştır. ${ }^{2} 1990^{\prime} l ı$ ylllarda benimsenen insani kalkınma yaklaşımı, 2011 yllında yayınlanan İnsani Gelişim Raporu'nda $^{3}$ sürdürülebilir kalkınma ile birleştirilerek "sürdürülebilir insani kalkınma yaklaşımı" olarak ele alınmaya başlamıştır. Sürdürülebilir kalkınma alanındaki önemli adımlardan birisi olan Binyıl Kalkınma Hedefleri de, 2000-2015 yılları arasında gelişmekte olan ülkeler için sekiz temel alandaki gelişimi ele almıştır.

2015 yılı dünya için önemli bir dönüm noktasını ifade etmektedir. Bu yıl içinde dünyadaki ülkelerin neredeyse tamamının katılımıla gerçekleşen iki önemli konsensüs ile küresel çapta, 2050 yılına kadar olan süreçteki yol haritasının sınırları belirlenmiştir. Konsensüslerden ilki Gündem 2030 ve Sürdürülebilir Kalkınma Amaçlarıdır ${ }^{4}$ (SDG). Gündemin içerdiği

1 Donella H. Meadows vd., The Limits to Growth: A Report for the Club of Rome's Project on the Predicament of Mankind (New York: Universe Books, 1972).

2 World Commission on Environment and Development, Our Common Future (Oxford: Oxford University Press, 1987). 3 United Nations Development Programme, Human Development Report 2011: Sustainability and Equity - A Better Future for All (New York: UNDP, 2011), http://hdr.undp.org/ sites/default/files/reports/271/hdr_2011_en_complete.pdf. 4 Sürdürülebilir Kalkınma Amaçları (İngilizce: Sustainable Development Goals, SDG) 
on yedi tane SDG; yoksulluğa son, açlığa son, sağlık ve kaliteli yaşam, nitelikli eğitim, toplumsal cinsiyet eşitliği, temiz su ve sanitasyon, erişilebilir ve temiz enerji, insana yakışır iş ve ekonomik büyüme, sanayi, yenilikçilik ve altyapı, eşitsizliklerin azaltılması, sürdürülebilir şehirler ve topluluklar, sorumlu üretim ve tüketim, iklim eylemi, sudaki yaşam, karasal yaşam, barış, adalet ve güçlü kurumlar, amaçlar için ortaklıklar, konularındaki amaçların 2030 yılına kadar gerçekleştirilmesini hedeflemektedir. Tüm amaçlar birbiriyle bağlantılıdır ve bir amacın gerçekleşmesindeki başarının anahtarı, birbiriyle bağlantılı sorunların hep birlikte ele alınmasında yatmaktadır ${ }^{5}$.

Bu yıl içindeki ikinci konsensüs ise Paris İklim Anlaşması için gerçekleşmiştir. 195 ülkenin onayıyla kabul edilen Paris İklim Anlaşması ise gezegendeki türlerin yaşamının sağlıklı bir şekilde devam edebilmesi için insan faaliyetleri kaynaklı küresel ısınmanın uzun vadede (2050 yllına kadar) sanayi devrimi öncesine göre $2^{\circ} \mathrm{C}$ 'nin altında tutulması ve hatta bu isınmayı $1.5^{\circ} \mathrm{C}$ ile sınırlamayı amaçlamaktadır. Bu kapsamda ülkelerin karbon salınımlarının kademeli olarak azaltılmasını hedeflemektedir. Bu anlaşma aynı zamanda 2030 Sürdürülebilir Kalkınma Gündemi çerçevesinde, daha istikrarlı, daha sağlıklı bir gezegen, daha adil toplumlar ve daha canlı ekonomilerin olduğu bir dünya oluşturabilmek adına da önemli bir fırsatı ifade etmektedir ${ }^{6}$. Her iki konsensüsün de dayandığı temel kavram ise sürdürülebilirlik ve bu bağlamda da sürdürülebilir kalkınmadır.

Sürdürülebilir kalkınmanın insanlık için ortak hedef olarak benimsendiği 1992 yılında Rio de Janeiro'da düzenlenen Birleşmiş Milletler Çevre ve Kalkınma Konferansı'ndan 20 yll sonra 2012 yılında Rio+20 Birleşmiş Milletler Sürdürülebilir Kalkınma Konferansında sürdürülebilir kalkınmanın gerçekleşebilmesi ve yoksulluğun ortadan kaldırılması bağlamında yeşil ekonominin en önemli araçlardan biri olarak görüldüğü ifade edilmiştir. Bu konferansın sonuç raporu; 2015 sonrası “Sürdürülebilir Kalkınma Hedeflerı" ile sürdürülebilir kalkınma konusunda atılacak adımları ve kararları içermekte, aynı zamanda yeşil büyüme gibi araçlarla sürdürülebilir kalkınmanın uluslararası düzeyde güçlendirilmesi için de bir çerçeve çizmektedir8.

Bu geniş kapsamlı sürdürülebilirlik gündeminin tüm dünyada hayata geçirilmesi sadece serbest piyasa güçlerinin işleyişi ile olanaklı olmadığı için, her alandaki dönüşüm, güçlü hükümetler önderliğinde iş dünyası ve sivil toplumun iş birliğini gerekli kılmaktadır. Diğer taraftan, SDG’ler ile bunlarla uyumlu politikaların 2030 yılına değin dünyadaki ülkelerin ulusal kalkınma stratejilerine entegrasyonunda, önerilen strateji ve politikaların mikro ve makro düzeylerde yönetiminde ve uygulanan politikaların performansının takibinde, ülkeler bazında ve küresel düzeyde karşılaştırılabilir olan bir veri devrimine ihtiyaç olduğunu ortaya koymaktadır9. "Veri Devrimi" kavramı ile ifade edilen mevcut veri türlerindeki/hacmindeki artış ve beraberinde, toplumu bilgilendirmek, dönüştürmek ve çevreyi korumak için benzeri görülmemiş olasıllklar yaratmaktır.

5 “Sürdürülebilir Kalkınma Amaçları,” UNDP Türkiye, Erişim Tarihi: 26 Ağustos 2020, https://www.tr.undp.org/content/ turkey/tr/home/sustainable-development-goals.html.

6 “Geleceğe Dair: Paris İklim Anlaşması," Avrupa Birliği Türkiye Delegasyonu, Erişim Tarihi: 20 Eylül 2020, https://www. avrupa.info.tr/sites/default/files/2016-08/brochure_4_v2.pdf.

7 “The Future We Want” Türkçe'ye “istediğimiz Gelecek” şeklinde çevrilmiştir.

8 “The Future We Want," Sürdürülebilir Kalkınma Türkiye, Erişim Tarihi: 10 Eylül 2020, http://www.surdurulebilirkalkinma.gov.tr/wp-content/uploads/2016/06/Future_We_Want.pdf.

9 Jeffrey Sachs vd., SDG Index and Dashboards Report 2018 (New York: Bertelsmann Stiftung and Sustainable Development Solutions Network, 2018), https://s3.amazonaws.com/sustainabledevelopment.report/2018/2018_sdg_index_and_ dashboards_report.pdf. 
Bu kapsamda 2015 yllından bu yana BM ve ilgili kuruluşlar bu çok boyutlu toplumsal dönüşüm için gerekli veri tabanını oluşturma konusunda çalışmaktadırlar. Türkiye de bu alanda bir çalışma programı oluşturmuş ülkeler arasında yer almaktadır.

Bunlar içinde Avrupa Birliği (AB) hem veri devrimi alanında yaptığı çalışmalarla, hem de sürdürülebilir bir ekonomik yapı oluşturmak üzere attığı adımlarla dünyada önemli bir referans oluşturmaktadır. $\mathrm{Bu}$ nedenle çalışmada $\mathrm{AB}$ ’nin sürdürülebilirlik gündemine farklı bir başlıkta yer verilmektedir.

\section{AB'nin Sürdürülebilirlik Gündemi}

Çevresel faaliyetlerdeki gelişim süreci Avrupa Toplulukları için 1970'lerde "Çevre Eylem Programları" ile başlamaktadır. Bu programlar ekolojik sorunlara sektörel bir yaklaşımla çözüm üretebilmeyi amaçlamakta ve genel olarak çevresel kirliliği azaltmaya yönelik mevzuatlardan oluşmaktadır. Zaman içerisinde ekonominin geneli içinde bu alan çevresel etkileri ölçmeye dayalı sistem geliştirmeye evrilmiştir. Geliştirilen bu sistemler çevresel sorunların tespiti ve bunlara uygun, gerçekçi politikaların üretilebilmesi için veri toplama sistemlerinin üretilmesine odaklanmıştır. 2000’li yılların başında Göteborg Avrupa Konseyi’nde kabul edilen sürdürülebilir kalkınma stratejisini uygulayarak sürdürülebilir büyümenin teşvik edilmesi Avrupa Birliği’nin önceliklerinden birisini oluşturmuştur.

AB'nin 2019 yılının sonunda dünya kamuoyuyla paylaştığı, AB'nin Paris İklim Anlaşması'nı doğrulayan şekilde 2050 yılına kadar karbon nötr olmasını hedefleyen Avrupa Yeşil Mutabakatı ${ }^{10}$ (AYM); $A B$ sanayisinin dönüşümünü öngören, yeni bir büyüme stratejisini ifade etmektedir. $\mathrm{Bu}$ strateji kapsamında; kimseyi geride bırakmadan yeni iş imkanları yaratılırken, karbon emisyonlarını da azaltmak hedeflenmektedir. Strateji ile yeşil, sürdürülebilir, kapsayıcı bir dönüşümle, insanların refahını ve gelecek nesiller için gezegenin sağlığının korunması amaçlanmaktadır. $\mathrm{Bu}$ kapsamda pek çok alanda etkisini gösterecek olan dönüşümün adil ve kapsayıcı olması gerekliliği de özellikle vurgulanmaktadır ${ }^{11}$. AYM’nin bir diğer özelliği de sadece çevreye yönelik bir strateji olmayıp, yeni bir uluslararası ticaret sistemi ve işbölümünü de içermesidir ${ }^{12}$.

Bu dönüşümün endüstride üç itici güç sayesinde gerçekleşmesi öngörülmekte ve sonucunda Avrupa'da endüstrinin yeşil, daha döngüsel ve daha dijital olması hedeflenmektedir. Bunu gerçekleştirecek itici güçlerin temelinin ise, yeşil dönüşüm, dijital dönüşüm ve küresel düzeyde rekabet gücü olduğu ifade edilmektedir ${ }^{13}$. Bu eksende ön plana çlkan bir diğer önemli araç olan döngüsel ekonomi ${ }^{14}$ de; üretimde ve tüketimde lineer modelin aksine, mevcut malzeme ve

\footnotetext{
10 European Green Deal

11 "The European Green Deal sets out how to make Europe the first climate-neutral continent by 2050, boosting the economy, improving people's health and quality of life, caring for nature, and leaving no one behind," European Commission, Erişim Tarihi: 25 Eylül 2020, https://ec.europa.eu/commission/presscorner/detail/e\%20n/ip_19_6691.

12 Türk Sanayicileri ve İş İnsanları Derneği, Ekonomik Göstergeler Merceğinden Yeni İklim Rejimi Raporu (İstanbul: TÜSiAD, 2020), https:/tusiad.org/tr/yayinlar/raporlar/item/10633-ekonomik-gostergeler-merceginden-yeni-i-klim-rejimi-raporu. 13 “A new Industrial Strategy for a globally competitive, green and digital Europe," European Commission, Erişim Tarihi: 25 Eylül 2020, https://ec.europa.eu/commission/presscorner/detail/en/fs_20_425.

14 Döngüsel ekonomi, ÇMHS çerçevesi içinde yer alan kaynak yönetimi alanıyla yakından ilişkilidir. Döngüsel ekonominin genel olarak kabul gören bir tanımı bulunmakla birlikte Avrupa Komisyonu'nun ifadesiyle; ürünleri mümkün olduğu kadar uzun süre kullanmayı, onarımı, yenilemeyi ve geri dönüştürmeyi içeren bir üretim ve tüketim modelidir. Bir ürün ömrünün
} 
ürünlerin yaşam döngüsünü uzatarak daha fazla değer yaratılmasını sağlamaktadır. Döngüsel ekonomi modeli Avrupa Yeşil Mutabakatı için de önemli bir yapı taşı olarak kabul edilmektedir.

$A B$ 'nin sürdürülebilirlik gündemi önümüzdeki dönemde diğer ülkelerle olan ticari faaliyetlerin şekillenmesinde önemli bir rol oynayacaktır. Bu eksende, ülkelerin yeşil politikalar ile mevcut ekonomik modellerini bu dönüșüme entegre etmesi öngörülmektedir. Sadece Avrupa'da değil dünyanın pek çok yerinde acil olarak gerçekleşmesine ihtiyaç duyulan dönüşümün hayata geçirilmesi ise, mevcut neo-liberal politikaların sürekli kendini tekrarlayan, kırılganlıkları ve eşitsizlikleri giderek arttıran sistemi ile eskisi gibi devam edilemeyeceğinin açık bir şekilde kabulüyle mümkün olacaktır.

\section{Dönüșümde Cevresel Sektörlerin Rolü}

Çevresel sektörlere ilişkin veri/bilgi toplanması ve bunların değerlendirilmesi ile, çevresel sektörlerin ekonomideki potansiyelinin ve dönüşümdeki rolünün belirlenmesi mümkün olacaktır. $\mathrm{Bu}$ kapsamda ihtiyaç duyulan verilerin toplanması, yeşil ekonomi ve yeşil büyümenin ekonomik konumunun ölçülebilmesi için Eurostat, BM ve OECD tarafından 1999 yllında çevresel faaliyetlerin tanımlarını ve özelliklerini belirten Çevresel Mal ve Hizmetler Sektörü (ÇMHS) çerçevesi geliştirilmiştir. Bu çerçeveye göre çevresel sektörlerin potansiyelini değerlendirebilmek için öncelikli ihtiyaç; dinamik, karşılaştırılabilir, temel göstergeleri içeren bir veri tabanının oluşturulmasıdır. Bunun için de ilk adım tüm ekonomi içerisinden çevre koruma ve kaynak yönetimine ilişkin faaliyetlerin belirlenmesi olacaktır. Pek çok ülkede özellikle 2005 dönemi itibariyle çevresel verilerin derlenmesine yönelik çalıșmalara bașlanmıștır. Günümüzde gelinen noktada karșılaștırılabilir verilerin üretimi konusunda, bu çalışmalara pek çok ülkede devam edilmektedir. Türkiye'de bu kapsamda kendi veri tabanını oluşturmak için çalışmalarını sürdürmekte ve veri toplamaktadır. Sürdürülebilir, kapsayıcı yeşil ekonomik dönüşümde sektörlere; yapılacak yatırımların ne şekilde ve hangi alana yapılmasının daha etkin sonuçlar doğuracağının tespit edilmesi, rekabette ön plana çıkabilecek noktaların belirlenebilmesi gibi kilit sorulara yanıt bulunması; bu sektörlerin çeşitli ekonomik değişkenler açısından analiz edilmesine bağlıdır. Bu konuda gerçekleştirilecek gerek teorik gerekse uygulamalı çalışmalara günümüzde her zamankinden daha çok ihtiyaç duyulmaktadır.

\section{Cevresel Sektörlerin Kapsamı}

Çalışmada çevresel sektörler ile ifade edilen ÇMHS çerçevesinden kısaca temel başlıklar altında bahsedilecek olursa; ÇMHS için genel tanımlama Eurostat tarafından şu şekilde yapılmaktadır: "Çevre endüstrisi veya eko-endüstriler olarak da adlandırlan çevresel mal ve hizmetler sektörü (ÇMHS); çevrenin korunmasını ve doğal kaynakların yönetimini amaçlayan heterojen bir mal ve hizmet üreticisi grubundan oluşmaktadir”15. ÇMHS çerçevesi 1990'lı yıllarda yapılan çalışmalarla şekillenmeye

sonuna geldiğinde malzemesi mümkün olan her şekilde ekonomi içinde tutulur. Bunlar tekrar tekrar verimli bir şekilde kullanılabilir hale getirilir.

15 “Environmental sector," Eurostat, Erişim Tarihi: 11 Eylül 2020, https://ec.europa.eu/eurostat/web/environment/environmental-sector. 
başlamıştır. Bu konuda literatürde ilk detaylı çalışma raporu 1992 yılında OECD tarafından yayınlanmıştır. Eurostat ve OECD’nin iş birliği ile 1996-1999 yılları içerisinde bu alandaki çalışmalar ilerletilmiş, 1999 yılında bu çalışmaların ortak bir ürünü olarak da ÇMHS hakkında o güne kadarki ilk kapsamlı yayın ve ilk el kitabı yayınlanmıştır. Bu tarihten itibaren ÇMHS çerçevesine ilişkin kapsamlı çalışmalar Eurostat tarafından yürütülmektedir ${ }^{16}$. ÇMHS; atık, kirlilik ve ekosistemler ile ilgili sorunların yanı sıra; su, hava ve topraktaki çevresel zararı ölçmek, önlemek, minimize etmek veya düzeltmek için mal ve hizmet üreten faaliyetlerden oluşmaktadır. Bu endüstrideki faaliyetler; çevresel riski azaltan, kirliliği ve doğal kaynak kullanımını en aza indiren daha temiz teknolojileri, mal ve hizmetleri içermektedir ${ }^{17}$.

ÇMHS’lerin üreticiler açısından kategorize edilmesinde ise iki önemli ayrım söz konusudur. Eğer bir sektördeki üreticiler; mallarını ve hizmetlerini tamamen çevresel amaçla üretiyorlarsa \%100 ÇMHS kategorisine aittirler ${ }^{18}$. Üretimlerinin tamamını değil kısmi olarak belli bir yüzdesinin çevresel olduğu, ya da üretimi çevresel olmadığı halde üretim çıktılarını çevresel amaçlarla kullanan üreticiler ise üretimlerinin çevresel yüzdesinin oranını ifade eden \%X ÇMHS kategorisinde ${ }^{19}$ yer alırlar.

ÇMHS verileri, çevresel faaliyetlerin amaçları göz önüne alınarak sınıflandırılmaktadır. Çevresel faaliyetlerin sınıflandırılmasının temelini oluşturan bu amaçlar aşağıdaki gibi iki kategoride incelenmektedir:

1. Çevre Koruma Faaliyetleri (ÇK)

2. Kaynak Yönetimi Faaliyetleri (KY)

Çevre koruma faaliyetleri kategorisi, Çevre Koruma Faaliyetleri Sınıflaması (CEPA 2000) kullanılarak çevre alanlarına bölünmüştür. Kaynak yönetimi kategorisine ait faaliyetler ise, Kaynak Yönetimi Faaliyetlerinin Sınıflamasına (CReMA 2008)'e göre metodolojide ayrılmıştır ${ }^{20}$. Bu iki sınıflama içinde CEPA, çevre koruma için genel, çok amaçlı, işlevsel bir sınıflandırmadır. Çevre koruma faaliyetlerinin, aynı zamanda ürünlerin, harcamaların ve diğer işlemlerin sınıflandırılmasında kullanılır. Uluslararası ekonomik ve sosyal sınıflandırma ailesinde yer alan tanınmış bir uluslararası standarttır. Türkiye'de çevresel veriler de bu sınıflama sistemi ile tutulmaktadır. Türkiye'de çevresel verilerinin programlı olarak toplanması; 2007-2011 Resmi İstatistik Programı ile başlamaktadır. Bu dönemde çevresel verilerin toplanması Türkiye İstatistik Kurumu (TÜIK) ile Çevre ve Orman Bakanlığı'nın sorumluluğuna verilmiştir ${ }^{21}$. Bu çalışmanın da konusunu oluşturan verilerin kaynağını ise daha çok çevresel muhasebe alanında ve sanayi için toplanan setler oluşturmaktadır. Bu da TÜíK’in sorumluluk alanındaki verilerin kapsamındadır. Çalışmada çevresel istihdamın analizi; 2010-2016 yılları kapsamında ele alınmaktadır²2. Türkiye ve TR31-İzmir

\footnotetext{
16 Pınar Börü, “Türkiye’de Çevresel Mal ve Hizmetler Sektörü: Çıktı, İstihdam, Yatırım ve Gelişme Potansiyelleri” (Doktora Tezi, Ege Üniversitesi, 2020), 37.

17 OECD/Eurostat, The Environmental Goods and Services Industry: Manual for Data Collection and Analysis (Paris: OECD Publishing, 1999), 9.

$18 \% 100$ ÇMHS kategorisine dahil olan sektörlerin tablosu ekte yer almaktadır.

19 \%X ÇMHS kategorisine dahil olan sektörler için "X” terimi ürün ve/veya hizmetin üretiminin çevresel yüzdesini ifade etmektedir. İlgili tablo ekte yer almaktadır.

20 CEPA ve CReMA sınıflamalarının detayları ekte yer almaktadır.

21 Türkiye İstatistik Kurumu, Çevre İstatistikleri, Sorularla Resmi İstatistikler 8 (Ankara: TÜiK, 2009).

22 Bu seçimde Türkiye'de girişimlere yönelik elde edilebilen bölgesel verilerin 2007 yılından itibaren derlenmesine rağ-
} 


\section{Çevresel Sektörlerin İzmir için Analizi}

İzmir için çevresel sektörlerin durumunun ve potansiyelinin belirlenmesinde; LQ (Yerelleşme Katsayısı) ve European Cluster Observatory platformunun 2007 yllında ortaya koyduğu bir teknik olan Üç Yıldız Analizi sonuçlarına göre değerlendirme yapılmaktadır. Bu analiz sonuçlarının değerlendirilmesinden önce İzmir'de çevresel sektörlerin çeşitli ekonomik değişkenlere göre mevcut durumu ele alınacaktır. Analiz için son yıl olan 2015'te Türkiye'nin genel ekonomisi içinde çevresel ekonominin istihdamı 81 bin kişidir $^{24}$. Bu değer aynı yılda toplam AB-28 için 4,4 milyon kişidir.

İzmir’de çevresel ekonominin tarım dışı istihdam değişkeni açısından Türkiye ekonomisi içindeki konumu ise 2015 yllı için şu şekildedir:

- Türkiye genel ekonomisi içinde İzmir'in istihdam payı yaklaşık \%6'dır²5.

- Türkiye'de çevresel ekonomi içinde İzmir'in istihdam payı \%5 civarındadır²6.

İzmir'de \%100 ÇMHS’e dahil olan her bir sektörün, ilgili sektörün Türkiye’deki büyüklüğüne göre oranlarına bakıldığında; istihdam değişkeni için \%42 oranıyla; ciro değişkeni için \%70 oranıyla; maaşlarda \%45 oranılla ilk sırada 3831-Hurdaların parçalara ayrlması sektörü gelmektedir. Onu ciroda ikinci sırada \%25 oranıla 3821-Tehlikesiz atıkların sslahı ve bertaraf edilmesi, istihdamda \%10 ve maaşlarda \%14 ile ikinci olarak 3832- Tasnif edilmiş materyallerin geri kazanımı sektörleri takip etmektedir. Bu sıralamada ciroda en düşük değeri alan sektör 3822-Tehlikeli atıkların ıslahı ve bertaraf edilmesi, istihdamda ve maaşlarda ise 2314- Cam elyaf imalatı sektörüdür.

men NACE Rev.2 revizyonunun geldiği tarih olan 2010 yılından itibaren kullanımı uygun görülmüştür. Çevresel veriler bu yıldan itibaren 2011 yılı hariç 2016 yılına kadar mevcuttur. Bu nedenle analizde son yıl olarak 2016 alınmıştır.

232015 'in en son yıl olarak alınması; TÜiK'in veri toplama yöntemindeki metodoloji değişikliğine dayanmaktadır. 20032015 yılları arasında "Yıllık Sanayi ve Hizmet İstatistikleri" ankete dayalı ve yerel birimleri içeren bölgesel düzeyde birlikte toplanmaktadır. 2015 sonrasında aynı veri setinin idari kayıtlara göre derlenmesine karar verilmiş ve 2016 öncesindeki veriler de 2009'a kadar revize edilmiştir.

24 Tarım dışı istihdam

25 Tarım dışı istihdam

26 TÜiK tarafından üretilen ve/veya yayımlanan istatistiklerin mikro verileri kullanılarak hesaplanmıştır. 
İzmir'in çevresel tüm sektörleri içinde ön plana çıan sektörleri ise aşağıda sıralama ve \% paylarına göre verilmektedir.

\begin{tabular}{|l|c|c|c|c|c|c|}
\hline & \multicolumn{2}{|l|}{ Ciro } & \multicolumn{2}{l|}{ İstihdam } & \multicolumn{2}{l|}{ Maaş ve Ücretler } \\
\cline { 2 - 7 } & Sıra & Pay\% & Sıra & Pay\% & Sıra & Pay\% \\
\hline $\begin{array}{l}2219 \text { - Diğer Kauçuk Ürünleri } \\
\text { Imalatı }\end{array}$ & 3 & 13 & 4 & 10 & 3 & 12 \\
\hline $\begin{array}{l}\mathbf{2 6 5 1} \text { - Ölçme, Test ve Seyrüsefer } \\
\text { Amaçlı Alet ve Cihazların Imalatı }\end{array}$ & 4 & 11 & 5 & 7 & 5 & 7 \\
\hline $\begin{array}{l}\mathbf{3 8 1 1} \text { - Tehlikesiz Atıkların } \\
\text { Toplanması }\end{array}$ & 5 & 8 & 2 & 16 & 2 & 23 \\
\hline $\begin{array}{l}\mathbf{3 8 3 1} \text { - Hurdaların } \\
\text { Parçalara Ayrııması }\end{array}$ & 1 & 15 & 9 & 4 & 10 & 2,5 \\
\hline $\mathbf{4 3 2 9}$ - Diğer Inş̧aat Tesisatı & 9 & 6 & 3 & 12 & 4 & 8 \\
\hline $\begin{array}{l}\mathbf{7 1 1 2} \text { - Mühendislik Faaliyetleri ve } \\
\text { Ilgili Teknik Danışmanlık }\end{array}$ & 2 & 14 & 1 & 30 & 1 & 25 \\
\hline
\end{tabular}

Tablo 1 İzmir'in Çeuresel Sektörlerindeki27 Ciro, İstihdam, Maaş ve Ücretler (2015)

Kaynak: TÜik tarafından üretilen ve/veya yayımlanan istatistiklerin mikro verileri kullanılarak hazırlanmıştır.

Bu tabloya göre; 7112-Mühendislik faaliyetleri ve ilgili teknik danışmanllk sektörü istihdam ile birlikte maaş ve ücretler değişkeni için de büyüklük olarak İzmir'deki tüm çevresel sektörler içinde ilk sırada yer almaktadır. Ciro için de \%14 oranıyla ikinci sırayı almaktadır. Ancak bu sektörde çevresel olan aslen 71.12.15 CPA ${ }^{28}$ kodlu, Atık Yönetimi Projeleri için Mühendislik Hizmetleri faaliyetidir. Türkiye için altı basamaklı bu düzeyde veri elde edilme imkânı olmadığı için bu faaliyeti temsilen 4 basamaklı NACE Rev.2'ye göre 7112 kodlu sektörün verileri kullanılmaktadır ${ }^{29}$. Bu nedenle tamamı çevresel kabul edilen 3831-Hurdaların Parçalara Ayrılması, İzmir'de çevresel sektörler içinde en yüksek ciro değerini alan, aynı zamanda Türkiye’nin aynı sektördeki istihdamının \%42’sini, cirosunun \%70’ini karşılayan konumu ile İzmir için çevresel sektörler içinde ekonomik değişkenler için yüksek uzmanlık göstermektedir.

2016 yılında Türkiye İstatistiki Bölge Birimleri Sınıflandırması ikinci düzeyindeki (İBBS-II) bölgeler içinde TR31-İzmir, Türkiye'nin çevresel istihdamının yaklaşık \%4'ünü oluşturmakta ve bu konumuyla 26 bölge içinde beşinci sırada yer almaktadır. TR10-İstanbul bu yıl için \%57 oranıyla ilk sırada, TR51- Ankara \%6,8 ile ikinci sırada, TR41-Bursa, Eskişehir, Bilecik \%6,7 ve TR42- Kocaeli, Sakarya, Düzce, Bolu, Yalova ise $\% 5,4$ oranı ile sırasıyla üçüncü ve dördüncü sırada yer almaktadırlar. 26 bölge içerisinde bu beş bölge Türkiye'nin çevresel istihdamının \%80’ini oluşturmaktadır.

\footnotetext{
27 Burada \%100 çMHS'ler kastedilmektedir.

28 Avrupa Ekonomik Topluluğunda Faaliyete Göre Ürünlerin İstatistiki Sınıflaması, 2008

29 Bahsedilen bu kısıt nedeniyle çalışmada benzer duruma sahip sektörler için hesaplamalar aynı varsayım ve yöntemlerle gerçekleştirilmiştir.
} 


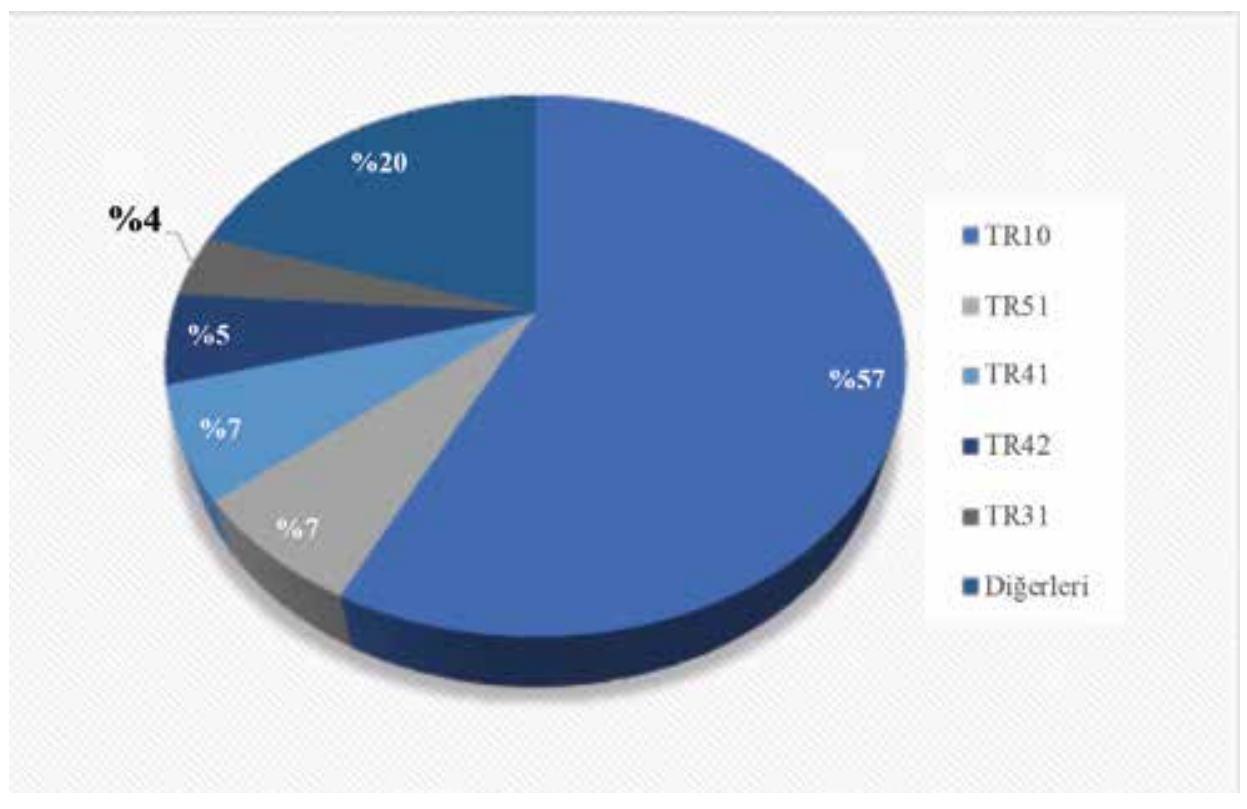

Şekil 1 Türkiye'nin Çeuresel İstihdamının İBBS-II Bölgeleri Düzeyinde Dağıımı [2016]

Kaynak: TÜiK tarafından üretilen ve/veya yayımlanan istatistiklerin mikro verileri kullanılarak hazırlanmıştır. ${ }^{30}$

Tüm bu çevresel sektör değerlendirmesine göre İzmir için, Türkiye’deki çevresel istihdamda genel olarak düşük bir değer almasına rağmen Türkiye'de ön plana çıan sektörlerinin belirlenmesi ve buna yönelik yatırım ve politikaların geliştirilmesi ile bölgenin çevresel potansiyelinin daha etkin değerlendirilmesi söz konusu olacaktır. Bu değerlendirmenin yapılmasında yol gösterici araçlar; bölüm başında değinilen LQ (Yerelleşme Katsayısı) ve bölgedeki istihdama göre çevresel sektörler için yapılan Üç Yıldız Analizidir. Aşağıda bu iki analizde İzmir'in değerlendirilmesi verilmektedir.

\section{İzmir için Yerelleșme Katsayısı (LQ) Analizi}

İzmir'de çevresel sektörlerin hangi alanlarda uzmanlaşma (yoğunlaşma) gösterdiğini belirleyebilmek amacıyla yerelleşme katsayıları (LQ) kullanılmıştır. 2015 yılına ilişkin TR31-İzmir bölgesinde çevresel istihdam için gerçekleştirilen LQ $^{31}$ analizine göre; \%100 ÇMHS’ler içinde 3831-Hurdaların parçalara ayrılması sektörünün uzmanlık katsayı değeri Türkiye'deki tüm bölgeler içinde ilk sırada yer almaktadır. Bu sektör bölgede yüksek uzmanlaşma göstermektedir. Onu 3832-Tasnif edilmiş materyallerin geri kazanımı sektörü izlemektedir. İzmir'de uzmanlaşma gösteren diğer \%100 çevresel sektörler sırasıyla; 2365-Lif ve çimento karışımlı ürünlerin imalatı, 2651-Ölçme, test ve seyrüsefer amaçl alet ve cihazların imalatı, 3821- Tehlikesiz atıkların ıslahı ve bertaraf edilmesi, 37-Kanalizasyon, 3812- Tehlikeli atıkların toplanması ve 3900-İyileştirme faaliyetleri ve diğer atı yönetimi hizmetleri'dir. Bunların dışında uzmanlaşma için en yakın aday 2219-Diğer kauçuk ürünleri imalatı'dır. Bu sektörün uzmanlık değeri 0.92 değerini almaktadır. \%X ÇMHS sonuçlarına bakıldığında ise İzmir'de uzmanlaşmada ilk sırada 2399- Başka yerde sınıflan-

30 TÜiK mikro veri setlerinden "Girişimlerde Çevresel Gelir, İstihdam ve Harcama İstatistikleri” veri seti kullanılarak girişimlerin çevresel istihdamı, Düzey 2 İstatistiki Bölge Birimleri Sınıflaması ile 26 alt bölge için hesaplanmıştır.

31 Burada geçen “Location Quotient” terimi “Yerelleşme Katsayısı” olarak çevrilmiştir. 
dırlmamış metalik olmayan diğer mineral ürünlerin imalatı'dır. İlk beșe giren diğer sektörler ise sırasıyla; 2016- Birincil formda plastik hammaddelerin imalatı, 3311- Fabrikasyon metal ürünlerin onarımı, 2813- Diğer pompaların ve kompresörlerin imalatı, 1920- Rafine edilmiş petrol ürünleri imalatı olarak sıralanmaktadır. ${ }^{32}$

\begin{tabular}{|c|c|c|c|c|}
\hline & \%100 ÇMHS & & \%X ÇMHS & \\
\hline & NACE Rev. 2 & LQ & NACE Rev.2 & LQ \\
\hline 1.Sektör & $\begin{array}{l}3831 \text { - Hurdaların parçalara } \\
\text { ayrılması }\end{array}$ & 7 & $\begin{array}{l}\text { 2399- Başka yerde } \\
\text { sınıflandırılmamış metalik olmayan } \\
\text { diğer mineral ürünlerin imalatı }\end{array}$ & 5,5 \\
\hline 2.Sektör & $\begin{array}{l}\text { 3832- Tasnif edilmiş materyallerin } \\
\text { geri kazanımı }\end{array}$ & 2 & $\begin{array}{l}\text { 2016- Birincil formda plastik } \\
\text { hammaddelerin imalatı }\end{array}$ & 5,2 \\
\hline 3.Sektör & $\begin{array}{l}\text { 2365- Lif ve çimento karışımlı } \\
\text { ürünlerin imalatı }\end{array}$ & 1,5 & $\begin{array}{l}\text { 3311- Fabrikasyon metal ürünlerin } \\
\text { onarımı }\end{array}$ & 4,9 \\
\hline 4.Sektör & $\begin{array}{l}2651 \text { - Ölçme, test ve seyrüsefer } \\
\text { amaçlı alet ve cihazların imalatı }\end{array}$ & 1,5 & $\begin{array}{l}\text { 2813- Diğer pompaların ve } \\
\text { kompresörlerin imalatı }\end{array}$ & 4,2 \\
\hline 5.Sektör & $\begin{array}{l}\mathbf{3 8 2 1} \text { - Tehlikesiz atıkların ıslahı ve } \\
\text { bertaraf edilmesi }\end{array}$ & 1,3 & $\begin{array}{l}\text { 1920- Rafine edilmiş petrol } \\
\text { ürünleri imalatı }\end{array}$ & 4,2 \\
\hline
\end{tabular}

Tablo 22015 Yılı için TR31-İzmir'de Uzmanlaşmada İlk Beş Sektör

Kaynak: Börü, 2020.

\section{İzmir için Üç Yıldız Analizi}

İzmir için çevresel sektörlerin her iki kategorisinde (\%100 ve \%X ÇMHS) hangi sektörlerin kümelenme gösterdiğinin tespiti için gerçekleştirilen üç yıldız analizi sonuçlarına göre uzmanlık, büyüklük ve baskınlık kriterlerinin her biri için eşik değerleri geçerek üç yıldız alan sektörler olgun kümeler, bu kriterlerin sadece iki tanesinde eşik değeri geçerek yıldız alan sektörler potansiyel kümeler, tek yıldız alabilenler ise aday kümeler olarak ifade edilmektedir.

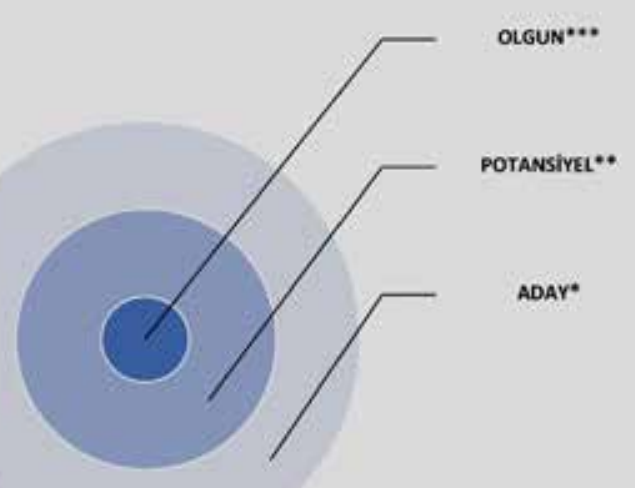


Bu sınıflamaya göre 2015 yllında çevresel sektörlerin İzmir'deki kümelenme potansiyeli değerlendirildiğinde \%100 ÇMHS’ler içinde olgun bir küme tespit edilememektedir. Aynı kategori için İzmir'deki potansiyel kümeler: 2365-Lif ve çimento karışıml ürünlerin imalatl, 2651-Ölçme, test ve seyrüsefer amaçl alet ve cihazların imalatı, 37-Kanalizasyon, 3812-Tehlikeli atıkların toplanması, 3821-Tehlikesiz atıkların ıslahı ve bertaraf edilmesi, 3831-Hurdaların parçalara ayrılması 3832-Tasnif edilmiş materyallerin geri kazanımı, 39-İyileştirme faaliyetleri ve diğer atı yönetimi hizmetleri sektörlerinden oluşmaktadır. Aday kümeler ise 2219-Diğer kauçuk ürünleri imalatı ve 7112-Mühendislik faaliyetleri ve ilgili teknik danışmanlık sektörlerini içermektedir.

\%X ÇMHS'ler içerisinde olgun kümeler; 1721-Oluklu kağıt ve mukavva imalatı ile kağıt ve mukavvadan yapılan muhafazaların imalatı, 2222-Plastik torba, çanta, poşet, çuval, kutu, damacana, şişe, makara vb. paketleme malzemelerinin imalatı, 2223-Plastik inşaat malzemesi imalatı, 2825Soğutma ve havalandırma donanımlarının imalatı ve 2932-Motorlu kara taşıtları için diğer parça ve aksesuarların imalatıdır.

Potansiyel kümeler içinde öne çıkan 10 sektör ise; 2399-Başka yerde sınıflandırılmamış metalik olmayan diğer mineral ürünlerin imalatı, 2016-Birincil formda plastik hammaddelerin imalat,, 3311-Fabrikasyon metal ürünlerin onarım,, 2813-Diğer pompaların ve kompresörlerin imalat,, 1920-Rafine edilmiş petrol ürünleri imalatı, 2030-Boya, vernik vb. kaplayıcı maddeler ile matbaa mürekkebi ve macunu imalatı, 1723-Kağıt kırtasiye ürünleri imalatı, 1624-Ahşap konteyner imalatı, 1729-Kağıt ve mukavvadan diğer ürünlerin imalatı, 2059-Başka yerde sinıflandirlmamış diğer kimyasal ürünlerin imalatı şeklindedir. Aday kümeleri ise bu kategoride 2362-İnşaat amaçlı alçı ürünlerin imalatı, 2451-Demir döküm, 2512-Metalden kapı ve pencere imalatı, 36-Suyun toplanması, arıtılması ve dağıtılması, 4120-İkamet amaçlı olan veya ikamet amaçlı olmayan binaların inşaatı, 4221-Akışkanlar için hizmet projelerinin inşaatı, 4399-Başka yerde sinıflandırılmamış diğer özel inşaat faaliyetleri sektörleri oluşturmaktadır. İzmir'in \%100 ve \%X ÇMHS’lerdeki kümelenmesi aşağıda (tablo 3) verilmektedir.

\begin{tabular}{|c|l|l|l|}
\hline & Olgun Küme & Potansiyel Küme & Aday Küme \\
\hline$\% 100$ & - & $\begin{array}{l}2365-2651-37-3812- \\
3821-3831-3832-39\end{array}$ & $2219-7112$ \\
\hline \multirow{2}{*}{$\%$} & $1721-2222-2223-2825-$ & $\begin{array}{l}2399-2016-3311-2813- \\
1920-2030-1723-1624-\end{array}$ & $\begin{array}{l}2362-2451-2512-36- \\
4120-4221-4399\end{array}$ \\
\hline
\end{tabular}

Tablo 3 İzmir'de Çeuresel Sektörlerin Üç Yıldız Analizine Göre Kümelenme Durumu [2015]

Kaynak: Börü, 2020.

Teknoloji ve bilgi yoğunlukları değerlendirildiğinde İzmir'deki imalat sanayindeki çevresel sektörlerinin yapısının; teknoloji yoğunluğunda orta yüksek ve orta düşük düzeyde, hizmetlerin bilgi yoğunluğunun ise düşük düzeyde olduğu görülmektedir. Aşağıda (şek. 3 ve şek. 4) bu durum detaylı olarak ele alınmaktadır. 


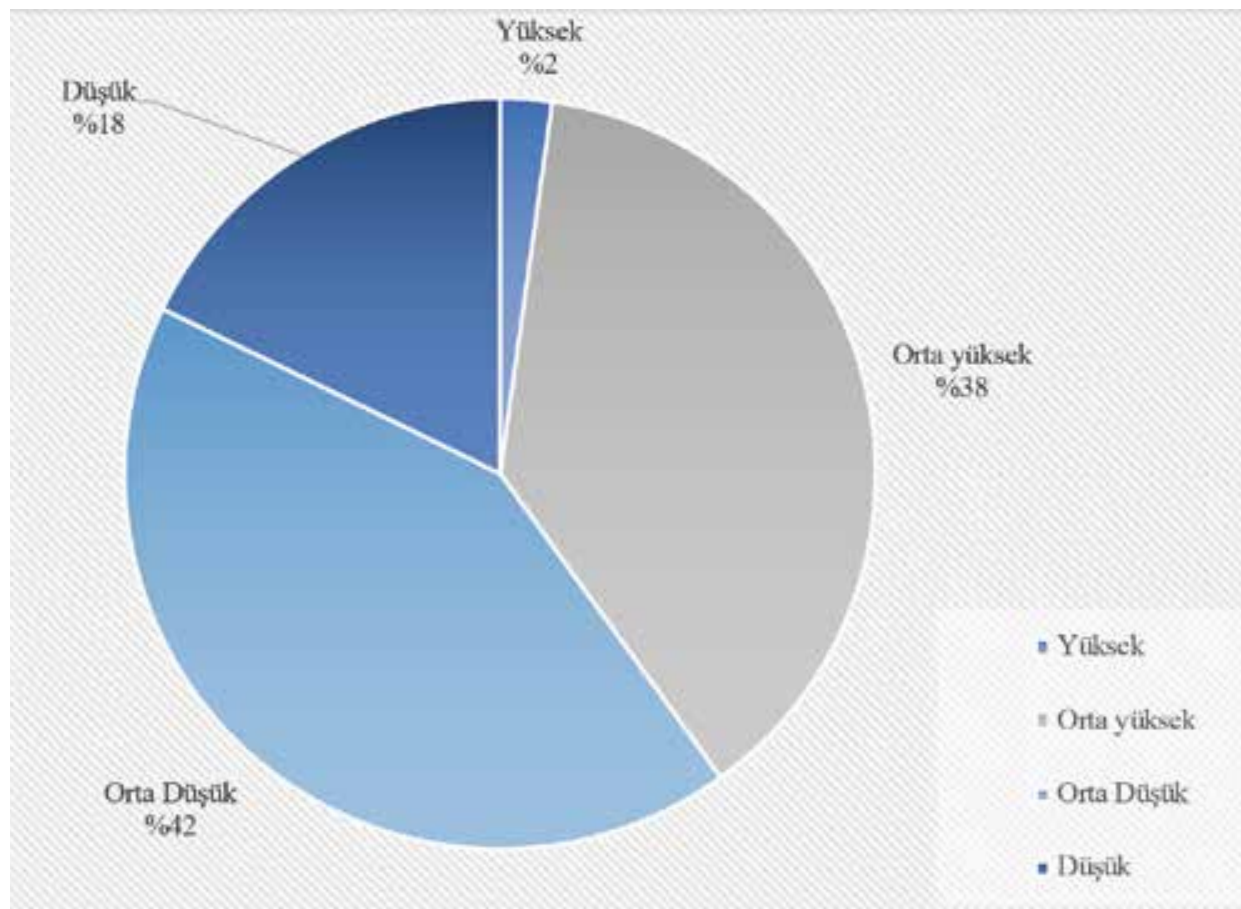

Şekil 3 İzmir'de Çeuresel Sektörlerin Teknoloji Yoğunlukları (2015)

Kaynak: Börü, 2020.

Buna göre; İzmir'de imalat sanayinde çevresel sektörlerin \%80'ini teknoloji yoğunluğu orta düşük ve orta yüksek sektörlerden oluşmaktadır. Yüksek teknoloji yoğunluğu İzmir için 2015 yllında sadece \%2 düzeyindedir. Hizmetler sektöründeki bilgi yoğunlukları ise aşağıda (şek. 4) verilmektedir.

\section{- Yüksck Bilgi Yoğun = Düșük Bilgi Yoğun}

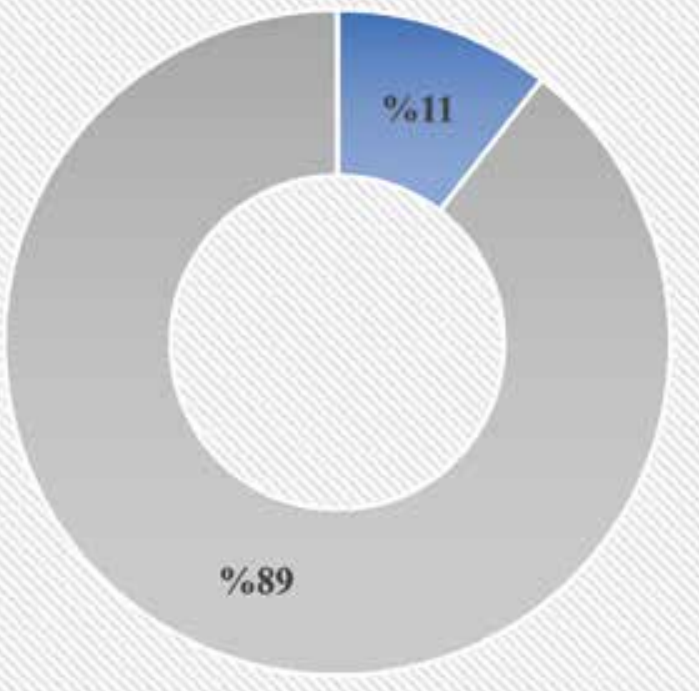


2015 yllında İzmir’deki çevresel sektörler \%89 oranında bilgi yoğunluğu düşük sektörlerden oluşmaktadır. Bunun temel sebebi çevresel sektörlerin ağırlıklı olarak çevre koruma ve atık toplamaya yönelik hizmetler sektöründe olmasıdır. İzmir için bunun en önemli örneği bölgede ön plana çıkan; gemi söküm ve atık geri kazanım faaliyetlerinin Türkiye genelinde gerek istihdam gerekse üretim değeri açısından en yüksek değerleri almasıdır. Bu sektörler uzmanlık, büyüklük ve baskınlık kriterlerinde İzmir'de olgun kümeler içerisinde yer almaktadırlar.

\section{Çevresel İstihdamın İzmir'de İlçeler Bazında Dağıımı}

İzmir için girişimler düzeyinde çevresel istihdamın ilçelere göre 2010-2016 yılları arasındaki ortalama dağılımına bakıldığında; Konak’ın İzmir’in çevresel istihdamı içindeki payının \%29 olduğu görülmektedir. Çevresel istihdam payında \%28 oranıyla Bornova ilçesi ikinci sıradadır. Aliağa ise çevresel istihdamdaki payının \%13’ünü alarak üçüncü ilçe konumunda yer almaktadır. Bu ilçeleri sırasıyla; \%7 ile Kemalpaşa, \%6 ile Gaziemir ve \%5 ile Torbalı takip etmektedir. İzmir’in çevresel istihdamındaki en büyük paya sahip olan bu altı ilçesi, İzmir'in toplam çevresel istihdamının da \%88'ini oluşturmaktadır.

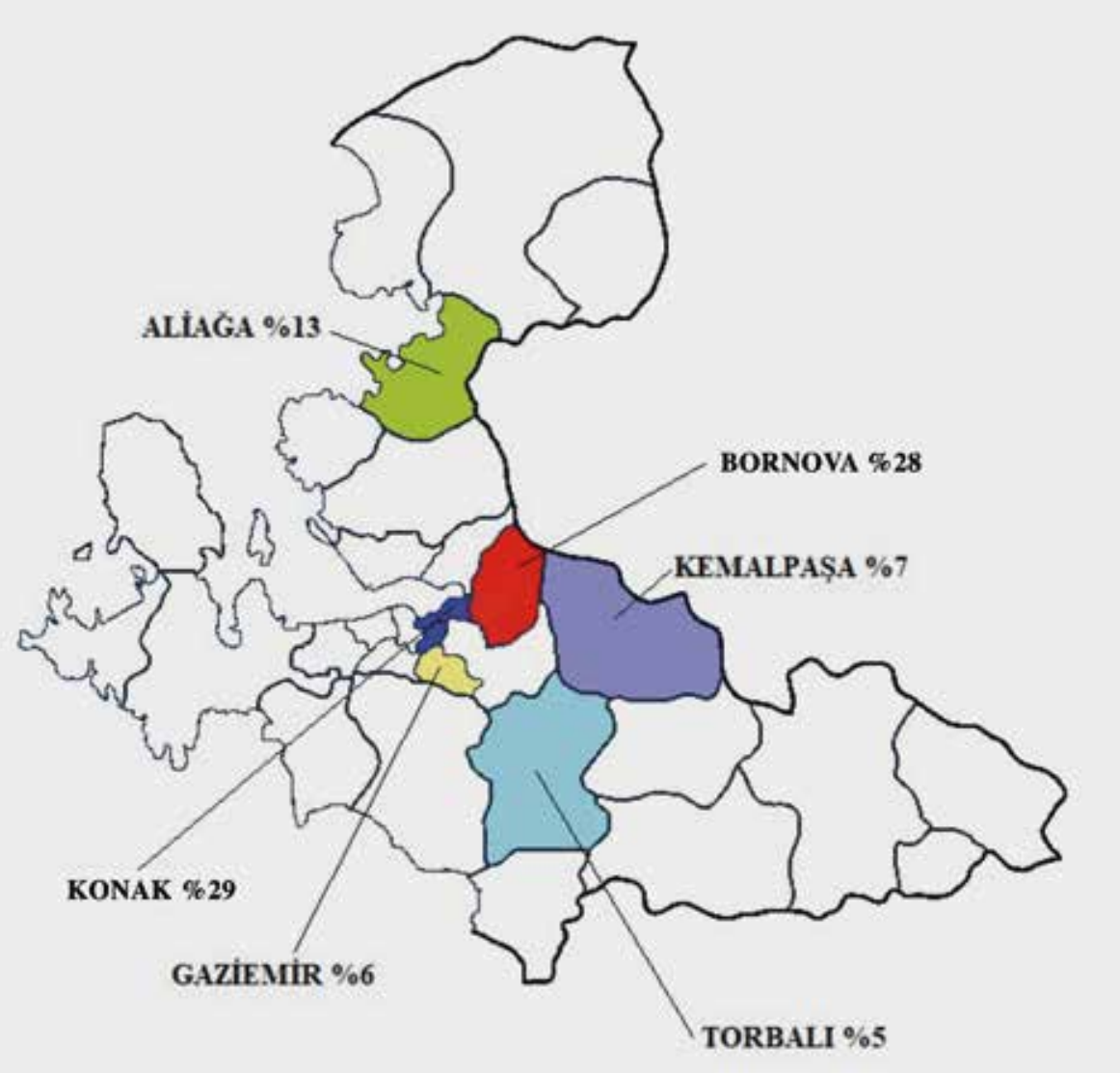

Şekil 5 Çevresel İstihdamın 2010-2016 Yılları Arasında İzmir İlçeleri Bazında Dağılımı

Kaynak: TÜiK tarafından üretilen ve/veya yayımlanan istatistiklerin mikro verileri kullanılarak hazırlanmıştır. ${ }^{33}$ 
Yukarıdaki LQ ve Üç Yıldız Analizi sonuçlarında İzmir, Türkiye genelinde NACE Rev.2 sınıflamasına göre 3831-Hurdaların Parçalara Ayrlmasında yüksek düzeyde uzmanlık göstermektedir. İzmir ilinde çevresel istihdamın daha çok Konak, Bornova ve Aliağa ilçelerinde yoğunlaşmasında hurdaların parçalara ayrılması ve tasnif edilmesi faaliyetlerinin önemli bir etkisinin olduğu düşünülmektedir.

\section{Tartıșma ve Sonuç}

İçinde bulunduğumuz COVID-19 kaynaklı pandemi de dahil olmak üzere dünyada ekolojik, ekonomik ve sosyal alanda sürekli kendini tekrarlayan çok boyutlu krizler gezegendeki tüm canlı türleri ve insanlık için yaşamı olumsuz yönde etkileyerek çok ciddi tehditler oluşturmaktadır. Esasen sanayi devrimi ile başlayıp, 1950'li yıllardan itibaren hızlanarak devam eden süreçte, gezegenimizdeki ekolojik sistemlere ilişkin pek çok parametrede, küresel ısınma ve iklim krizi, biyoçeşitlilik kayıpları, temiz suya erişim sorunu, hava kirliği, nitrojen ve fosfor döngülerine bağlı toprağın verimlilik kaybı vb. yeryüzünün biyofiziksel kapasitesindeki sınırların aşılması söz konusudur. $^{34}$ Artık sürdürülemez bir noktaya gelen insanlığın tüketim ve üretim örüntülerinin dönüştürülmesi bu krizlerin aşılabilmesi için tek çare olarak görülmektedir. Bu dönüşümün ne şekilde yapılabileceğine ilişkin uzun yıllar boyunca pek çok ülkede çeşitli çalışmalar gerçekleştirilmiştir. Özellikle bu dönüşüm için 2015 yllı tarihte önemli bir noktayı işaret etmektedir. Çalışmanın başında da bahsedildiği gibi bu yıl içinde dünyadaki ülkelerin neredeyse tümünün katılımıyla iki önemli konsensüs hayata geçirilmiştir. Bu konsensüsler 2050 yılına kadar bu dönüşüme öncülük edecek bir yol haritası sunmaktadır. Bu dönüşümün gerçekleşmesi insanların üretimlerinde ve tüketimlerinde gezegenle uyumlu olmasını gerekli kılmaktadır. Bu nedenle ülkelerin gerek sanayilerinde gerek ticaret ve finans sistemlerinde gerekse sosyal sistemlerinde gezegenle uyumlu, sürdürülebilir ve daha kapsayıcı bir yapıya doğru evrimi söz konusu olmalıdır. Bunun gerçekleşmesi için bir diğer önemli ön koşul da mevcut ekonominin bu dönüşüme entegre edilmesinde doğru stratejilerin belirlenebilmesidir. Doğru stratejilerin belirlenmesi ve bunlarla uyumlu yeşil ekonomi ve yeşil büyüme stratejilerinin performansının izlenebilmesi için de küresel karşılaştırılabilir veriye ihtiyaç duyulmakta ve bu verilerin en etkin ve en hızlı sonucu alacak şekilde değerlendirilmesi gerekmektedir.

Eurostat ve OECD’nin geliştirmiş olduğu ÇMHS ölçme değerlendirme çerçevesi ve metodolojisi kullanılarak İzmir için gerçekleştirilen bu çalışma ile, bölgedeki yeşil politikalara ilişkin göstergeler oluşturulması, izlenen politikaların performansının değerlendirilebilmesinde ihtiyaç duyulan bilginin sağlanmasına katkı vermek amaçlanmıştır.

Bu eksende çalışmada çevresel sektörlerin uzmanlaşma ve kümelenme durumlarının tespitine yönelik analizlere yer verilmiştir. Her ne kadar çevresel ekonominin genel ekonomi içindeki payları düşük olsa da özellikle istihdam yaratmada genel ekonomiden çok daha iyi performans sergilemektedir. ${ }^{35}$

Düzey 2 İstatistiki Bölge Birimleri Sınıflaması ile 26 alt bölge için hesaplanan girişimlerin çevresel istihdamı; TR31-İzmir bölgesindeki girişimler için ilçeler düzeyinde de hesaplanmıştır.

34 Johan Rockström vd., "Planetary Boundaries: Exploring the Safe Operating Space for Humanity," Ecology and Society

14, s. 2 (2009).

35 Börü, "Türkiye'de Çevresel Mal ve Hizmetler Sektörü," 94. 
Çevresel sektörlerin sahip olduğu potansiyelin, ekonomideki konumunun ve yaratacağı etkinin ölçülmesi önümüzdeki dönemi şekillendirecek ulusal ve bölgesel yeşil politikalar için kaynak teşkil etmekte ve bu alanda oluşturulacak dinamik veri tabanlarına özellikle ihtiyaç duyulmaktadır. Bu çalışma da bu veri tabanına İzmir ili/bölgesi için bir katkı sunmak amacıyla gerçekleştirilmiştir. İzmir için çevresel sektörlerin öne çıkan noktaları özetlenecek olursa:

- İzmir için yapılan çevresel sektör analizlerinde özellikle bölgede çevresel sektörler içinde en yüksek ciro değerini yaratmasıyla 3831-Hurdaların parçalara ayrılması ön plana çıkan sektör olarak belirlenmiştir. Bunun yanında 7112-Mühendislik faaliyetleri ve ilgili teknik danışmanlık sektörü istihdam ile birlikte maaş ve ücretler değişkeni için de büyüklük olarak İzmir’deki tüm çevresel sektörler içinde ilk sırada yer almaktadır.

İzmir için gerçekleştirilen LQ analizi sonuçlarına göre bölgede \%100 ÇMHS’ye dahil olan 3831-Hurdaların parçalara ayrılması ve 3832-Tasnif edilmiş materyallerin geri kazanımı uzmanlaşmada ilk sıralarda, \%X ÇMHS’ye dahil olanlardan ise 2399-Başka yerde sınıflandırılmamış metalik olmayan diğer mineral ürünlerin imalatı ve 2016-Birincil formda plastik hammaddelerin imalatı ilk sıralarda yer almaktadır.

- Üç yıldız analizi sonuçlarına göre bölgenin çevresel sektörlerindeki kümelenmeler değerlendirildiğinde; \%100 ÇMHS’ler içinde olgun bir küme tespit edilememektedir. Aynı kategori için İzmir'deki potansiyel kümeler: 2365-Lif ve çimento karışıml ürünlerin imalatı, 2651-Ölçme, test ve seyrüsefer amaçlı alet ve cihazların imalatı, 37-Kanalizasyon, 3812-Tehlikeli atıkların toplanması, 3821-Tehlikesiz atıkların ıslahı ve bertaraf edilmesi, 3831-Hurdaların parçalara ayrılması, 3832-Tasnif edilmiş materyallerin geri kazanımı, 39-İyileştirme faaliyetleri ve diğer atık yönetimi hizmetleri sektörlerinden oluşmaktadır. Aday kümeler ise 2219- Diğer kauçuk ürünleri imalatı ve 7112- Mühendislik faaliyetleri ve ilgili teknik danışmanllk sektörlerini içermektedir. \%X ÇMHS’ler içerisinde olgun kümeler; 1721-Oluklu kağıt ve mukavva imalatı ile kağıt ve mukavvadan yapılan muhafazaların imalatı, 2222-Plastik torba, çanta, poşet, çuval, kutu, damacana, şişe, makara vb. paketleme malzemelerinin imalatı, 2223-Plastik inşaat malzemesi imalatı, 2825-Soğutma ve havalandırma donanımlarının imalatı ve 2932-Motorlu kara taşıtları için diğer parça ve aksesuarların imalatıdır. Potansiyel kümeler içinde öne çıkan sektörler ise; 2399-Başka yerde sinıflandırılmamış metalik olmayan diğer mineral ürünlerin imalatı, 2016-Birincil formda plastik hammaddelerin imalatı, 3311-Fabrikasyon metal ürünlerin onarımı, 2813-Diğer pompaların ve kompresörlerin imalatı, 1920-Rafine edilmiş petrol ürünleri imalatı, 2030-Boya, vernik $v b$. kaplayıcı maddeler ile matbaa mürekkebi ve macunu imalatı, 1723-Kă̆gt kırtasiye ürünleri imalatı, 1624-Ahşap konteyner imalatl, 1729-Kağıt ve mukavvadan diğer ürünlerin imalatı, 2059-Başka yerde sinıflandırlmamış diğer kimyasal ürünlerin imalatı şeklindedir. Aday kümeleri ise bu kategoride 2362-İnşaat amaçlı alçı ürünlerin imalatı, 2451-Demir döküm, 2512-Metalden kapı ve pencere imalatl, 36-Suyun toplanması, arıtılması ve dağıtılması, 4120-İkamet amaçlı olan veya ikamet amaçlı olmayan binaların inşaatı, 4221-Akışkanlar için hizmet projelerinin inşaatı, 4399-Başka yerde sinıflandırlmamış diğer özel inşaat faaliyetleri sektörleri oluşturmaktadır

- İzmir'de çevresel sektörlerin imalatta ve hizmetlerdeki teknoloji ve bilgi yoğunlukları değerlendirildiğinde, İzmir’in çevresel sektörlerinin ekosisteminin genel olarak teknolojide \%80'inin orta yüksek ve orta düşük olduğu, hizmetler sektörünün ise sadece \%11’inin bilgi yoğunluğu yüksek olan sektörlerden oluştuğu görülmektedir. 
- İzmir'in ilçeleri için yapılan çevresel istihdamın LQ ve Üç Yıldız Analizinin bulgularını doğrular şekilde Konak, Bornova ve Aliağa ilçelerinde yoğunlaşmasında; hurdaların parçalara ayrılması ve tasnif edilmesi, materyallerin geri dönüştürülmesi faaliyetlerinin önemli bir etkisinin olduğu düşünülmektedir.

- Türkiye İstatistiki Bölge Birimleri Sınıflandırması ikinci düzeyindeki (İBBS-II) 26 bölge içinde çevresel istihdamda; \%4 oranı ile 5. sırayı almaktadır.

Türkiye için gerçekleştirilen analizlerde çevresel sektörler içinde diğer bölgelerden büyüklük olarak arka planda kalmasına rağmen İzmir, yeşil bir üretim ve tüketim şehri olarak da önemli bir altyapiya sahiptir. Bu potansiyelin bütüncül bir şekilde, tüm ekosistemiyle ortaya konulabilmesi, şehrin Türkiye için önemli bir model olması ve dünyada ön plana çıkabilmesi için bir fırsat olarak görülüp, değerlendirilmelidir. Çevresel dönüşümde en önemli nokta; ülke ya da bölge için sahadan toplanan verilerle ülke/bölge ekonomisinin doğru bir şekilde konumlandırllabilmesi, analiz sonuçlarına ve deneyimlere göre doğru yatırımlarla desteklenmesidir.

Üç yıldız ve uzmanlaşma analizlerinde İzmir için ön plana çıan geri dönüşüm sektörlerine ayrı bir parantez açmak gerekirse: Başta da vurgu yapıldığı üzere mevcut sistemimiz için üretimde doğal kaynak kullanımı artık sürdürülemez bir noktaya gelmiştir. Üretimin kaynaklar üzerinde yarattığı bu baskının azaltılmasında izlenebilecek yol; ürünlerin verimli bir şekilde geri dönüşümünün gerçekleştirilmesini içeren döngüsel ekonomiyi ülkelerin üretim ve tüketim biçimlerine uyarlamasıdır. Döngüsel ekonomide ana unsurlardan olan geri dönüştürülmüş materyallerin hammadde olarak kullanımı, özellikle Türkiye'de bu alandaki sektörlerde yüksek uzmanlaşma gösteren İzmir için önemli bir potansiyel yaratmaktadır. İzmir için atıkların ve geri dönüştürülmüş materyallerin çevre için zararsız bir formata dönüştürülerek yeniden kullanılabilir hale getirilebilmesini sağlayan teknolojileri ve bilgiyi üretebilen, bu alanda öncü olarak çevresel teşvikleri, yatırımları dünyadan alabilecek bir pozisyona getirilmesi için gerekli düzenlemelerin yapılması, endüstriyel simbiyozların oluşturulması, bunların gerek kurumlar gerekse sanayi ve üniversite iş birlikleri ekseninde bölgenin mikro, mezo ve makro aktörlerini kapsayacak şekilde gerçekleştirilmesi, bu alanda yaratılmış olan değeri İzmir için fark yaratan bir faydaya çevirebilecektir.

Bu çalışmada mevcut verilerden yola çıkılarak İzmir’in çevresel sektörlerindeki potansiyeli ortaya konulmuştur. Çalışma veri analizindeki kısıtlar nedeniyle genel olarak tarım dışı sektörleri kapsamakta ve analizler tüm sektörler için dört basamakta gerçekleştirilmektedir. Gerçekleştirilen bu analizlerin farklı şekillerde detaylandırılması bundan sonra yapılacak çalışmalar için bir öneri olarak sunulmaktadır. İzmir çevresel sektörlerin kategorilerinden \%X ÇMHS sektörleri açısından da önemli bir potansiyeli barındırmaktadır. \%X ÇMHS’ler içerisinde ön plana çıkan sektörlerin saha çalışmalarıyla desteklenerek çevresel yüzdesinin belirlenmesi bölge için çevresel sektörlerin gerçek potansiyelinin ortaya konulabilmesinde önem arz etmektedir. İzmir özelinde 2015 sonrasında bölgedeki yatırımlar içinde özellikle rüzgâr enerjisine yönelik önemli gelişmeler söz konusu olmuştur. Bu örnekten yola çıkarak; bu ve benzer sektörleri besleyen ileri ve geri bağlantıların tespiti ile çevresel etkinin çok daha doğru konumlandırılması ve ölçümü mümkün olabilir. Özellikle organik tarım konusunda Türkiye içinde ön sıralarda yer alan İzmir'de yapılacak çalışmaların da bölgenin yarattığı ve yaratacağı değerin belirlenmesi için çok önemli bir rolü olacaktır. Ayrıca AB’nin yeşil mutabakat düzenlemeleri kapsamında önümüzdeki dönemde İzmir'de etkilenebilecek sektörlerin tespiti ve bu kapsamda oluşturulacak stratejiler konusunda geç kalmadan hazırlıklarını yapmalıdır. Bu çalışmanın da İzmir'de bu alanda yapılacak çalışmalar için yol göstermesi beklenmektedir. 
Avrupa Birliği Türkiye Delegasyonu. "Geleceğe Dair: Paris İklim Anlaşması.” Erişim Tarihi: 20 Eylül 2020. https:/www.avrupa.info.tr/sites/default/files/2016-08/ brochure_4_v2.pdf.

Börü, Pınar. “Türkiye'de Çevresel Mal ve Hizmetler Sektörü: Çıktı, İstihdam, Yatırım ve Gelişme Potansiyelleri." Doktora Tezi, Ege Üniversitesi, 2020.

European Commission. "The European Green Deal sets out how to make Europe the first climate-neutral continent by 2050 , boosting the economy, improving people's health and quality of life, caring for nature, and leaving no one behind." Erişim Tarihi: 25 Eylül 2020. https://ec.europa.eu/commission/presscorner/ detail/e\%20n/ip_19_6691.

European Commission. "A new Industrial Strategy for a globally competitive, green and digital Europe." Erişim Tarihi: 25 Eylül 2020. https://ec.europa.eu/commission/presscorner/detail/en/fs_20_425.

Eurostat. “Environmental sector." Erişim Tarihi: 11 Eylül 2020. https://ec.europa.eu/eurostat/web/environment/environmental-sector.

Meadows, Donella H., Dennis L. Meadows, Jørgen Randers, ve William W. Behrens III. The Limits to Growth: A Report for the Club of Rome's Project on the Predicament of Mankind. New York: Universe Books, 1972.

OECD/Eurostat. The Environmental Goods and Services Industry: Manual for Data Collection and Analysis. Paris: OECD Publishing, 1999.

Rockström, Johan, Will Steffen, Kevin Noone, Åsa Persson, F. Stuart III Chapin, Eric Lambin, Timothy M. Lenton, Marten Scheffer, Carl Folke, Hans Joachim Schellnhuber, Björn Nykvist, Cynthia A. de Wit, Terry Hughes, Sander van der Leeuw, Henning Rodhe, Sverker Sörlin, Peter K. Snyder, Robert Costanza, Uno Svedin, Malin Falkenmark, Louise Karlberg, Robert W. Corell, Victoria J. Fabry, James Hansen, Brian Walker, Diana Liverman, Katherine Richardson, Paul Crutzen, ve Jonathan Foley. "Planetary Boundaries: Exploring the Safe Operating Space for Humanity." Ecology and Society 14, s. 2 (2009).

Sachs, Jeffrey, Guido Schmidt-Traub, Christian KroII, Guillaume Lafortune, ve Grayson Fuller. SDG Index and Dashboards Report 2018. New York: Bertelsmann Stiftung and Sustainable Development Solutions Network, 2018. https://s3.amazonaws.com/sustainabledevelopment.report/2018/2018_sdg_index_and_ dashboards_report.pdf.

Sürdürülebilir Kalkınma Türkiye. "The Future We Want." Erişim Tarihi: 10 Eylül 2020. http://www.surdurulebi-
Türkiye İstatistik Kurumu. Çevre İstatistikleri. Sorularla Resmi İstatistikler 8. Ankara: TÜiK, 2009.

Türk Sanayicileri ve İş İnsanları Derneği. Ekonomik Göstergeler Merceğinden Yeni İklim Rejimi Raporu. İstanbul: TÜSIAD, 2020. https://tusiad.org/tr/yayinlar/ raporlar/item/10633-ekonomik-gostergeler-merceginden-yeni-i-klim-rejimi-raporu.

UNDP Türkiye. "Sürdürülebilir Kalkınma Amaçları." Erişim Tarihi: 26 Ağustos 2020. https://www.tr.undp. org/content/turkey/tr/home/sustainable-development-goals.html.

United Nations Development Programme. Human Development Report 2011: Sustainability and Equity - A Better Future for All. New York: UNDP, 2011. http://hdr. undp.org/sites/default/files/reports/271/hdr_2011_ en_complete.pdf.

World Commission on Environment and Development. Our Common Future. Oxford: Oxford University Press, 1987. 
Ek 1. Çevresel Faaliyet Sınıflamaları

\begin{tabular}{|c|l|c|l|}
\hline & CEPA* & & CReMA** \\
\hline 1 & Atmosfer ve iklimi koruma & $11 \mathrm{~A}$ & Ekili olmayan orman alanlarının yönetimi \\
\hline 2 & Atık su yönetimi & $11 \mathrm{~B}$ & $\begin{array}{l}\text { Orman kaynakları kullanımının en aza } \\
\text { indirgenmesi }\end{array}$ \\
\hline 3 & Atık yönetimi & 12 & Yabani hayvan ve bitkilerin yönetimi \\
\hline 4 & $\begin{array}{l}\text { Toprak, yeraltı ve yüzey suyu koruma ve } \\
\text { iyileştirme }\end{array}$ & 13 & Enerji kaynaklarının yönetimi \\
\hline 5 & Gürültü ve titreşim azaltma & $13 \mathrm{~A}$ & Yenilenebilir kaynaklardan enerji üretimi \\
\hline 6 & $\begin{array}{l}\text { Biyolojik çeşitliliğin ve } \\
\text { peyzajın korunması }\end{array}$ & $13 \mathrm{~B}$ & Isı/Enerji tasarrufu ve yönetimi \\
\hline 7 & Radyasyona karşı koruma & $13 \mathrm{C}$ & $\begin{array}{l}\text { Ham fosil kaynaklarının alımının en aza } \\
\text { indirilmesi }\end{array}$ \\
\hline 8 & Çevre koruma için Ar-Ge & 14 & Maden yönetimi \\
\hline 9 & Diğer çevre koruma faaliyetleri & 15 & Kaynak yönetimi için Ar-Ge \\
\hline 10 & Su yönetimi & 16 & Diğer doğal kaynak yönetim faaliyetleri \\
\hline 11 & Orman kaynaklarının yönetimi & Kayre Koruma Faaliyetleri Sınıflaması *Kaynak Yönetimi Faaliyetleri Sınıflaması \\
\hline Kaynak: Eurostat & & & \\
\hline
\end{tabular}

\begin{tabular}{|c|c|c|c|c|c|}
\hline SAYI & $\begin{array}{l}\text { NACE } \\
\text { Kısım }\end{array}$ & $\begin{array}{l}\text { NACE } \\
\text { Sinıf }\end{array}$ & CPA & $\begin{array}{l}\text { CEPA } \\
\text { CReMA }\end{array}$ & CPA Kodlarının Açıklamaları \\
\hline 1 & A & 01.29 & 01.29 .10 & $13 C$ & Doğal kauçuk \\
\hline 2 & B & 08.12 & 08.12 .13 & 14 & $\begin{array}{l}\text { İnşaatlarda kullanılan cüruf ve benzeri sanayi } \\
\text { atık ürünlerinin karışımları (çeşitli çakıl, taş ve } \\
\text { çakmaktaşı karıştırılmış olsun veya olmasın) }\end{array}$ \\
\hline 3 & C & 22.11 & 22.11 .2 & $13 C$ & $\begin{array}{l}\text { Dış lastikler, havalı (pnömatik), sırt geçirilmiş, } \\
\text { kauçuk olanlar }\end{array}$ \\
\hline 4 & C & 22.19 & 22.19 .1 & $13 C$ & $\begin{array}{l}\text { Rejenere kauçuk, birincil formda veya levha, } \\
\text { tabaka veya şerit halinde }\end{array}$ \\
\hline 5 & C & 23.65 & 23.65 .11 & 3 & $\begin{array}{l}\text { Levha, blok ve benzeri ürünler (bitkisel lif, saman } \\
\text { veya ağaç döküntülerinin mineral bağlayıcılar ile } \\
\text { aglomera edilmesiyle elde edilenler) }\end{array}$ \\
\hline 6 & C & 26.51 & 26.51 .41 & 7 & $\begin{array}{l}\text { İyonlaştırıcı radyasyon belirleme veya ölçme için } \\
\text { kullanılan alet ve cihazlar }\end{array}$ \\
\hline 7 & C & 28.11 & 28.11 .22 & $13 \mathrm{~A}$ & Hidrolik türbinler ve su çarkları \\
\hline 8 & $C$ & 28.11 & 28.11 .24 & $13 \mathrm{~A}$ & Rüzgar türbinleri \\
\hline
\end{tabular}




\begin{tabular}{|c|c|c|c|c|c|}
\hline 9 & $\mathrm{C}$ & 28.11 & 28.11 .32 & $13 \mathrm{~A}$ & $\begin{array}{l}\text { Hidrolik türbinlerin ve su çarklarının parçaları, } \\
\text { regülatörler dahil }\end{array}$ \\
\hline 10 & $\mathrm{E}$ & - & 37 & 2 & Kanalizasyon hizmetleri; kanalizasyon çamuru \\
\hline 11 & $\mathrm{E}$ & & 38.1 & 3 & Atık; atık toplama hizmetleri \\
\hline 12 & $\mathrm{E}$ & 38.21 & 38.21 & 3 & $\begin{array}{l}\text { Tehlikesiz atıkların işlenmesi ve bertarafı } \\
\text { hizmetleri }\end{array}$ \\
\hline 13 & $\mathrm{E}$ & 38.22 & 38.22 & 3 & Tehlikeli atıkların işlenmesi ve bertaraf hizmetleri \\
\hline 14 & $\mathrm{E}$ & 38.22 & 38.22 .11 & 7 & Nükleer atıkların işlenmesi hizmetleri \\
\hline 15 & $\mathrm{E}$ & - & 38.3 & $11 \mathrm{~B}, 13 \mathrm{C}, 14$ & $\begin{array}{l}\text { Malzemelerin geri kazanımı hizmetleri; ikincil } \\
\text { hammaddeler }\end{array}$ \\
\hline 16 & $\mathrm{E}$ & 38.32 & 38.32 .11 & 14 & $\begin{array}{l}\text { Tasnif edilmiş metal malzemelerin geri kazanımı } \\
\text { hizmetleri }\end{array}$ \\
\hline 17 & $\mathrm{E}$ & 38.32 & 38.32 .12 & $11 \mathrm{~B}, 13 \mathrm{C}, 14$ & $\begin{array}{l}\text { Tasnif edilmiş metal dışı malzemelerin geri } \\
\text { kazanımı hizmetleri }\end{array}$ \\
\hline 18 & $\mathrm{E}$ & 38.32 & 38.32 .2 & 14 & Metal ikincil hammaddeler \\
\hline 19 & $\mathrm{E}$ & 38.32 & 38.32 .3 & $11 \mathrm{~B}, 13 \mathrm{C}, 14$ & Metal dışı ikincil hammaddeler \\
\hline 20 & $\mathrm{E}$ & 39.00 & 39.00 .11 & 4 & $\begin{array}{l}\text { Toprak ve yer altı suları iyileştirme ve temizleme } \\
\text { hizmetleri }\end{array}$ \\
\hline 21 & $\mathrm{E}$ & 39.00 & 39.00 .12 & 2 & Yüzey sularını iyileştirme ve temizleme hizmetleri \\
\hline 22 & $\mathrm{E}$ & 39.00 & 39.00 .13 & 1 & Hava iyileştirme ve temizleme hizmetleri \\
\hline 23 & $\mathrm{E}$ & 39.00 & 39.00 .23 & $1, . ., 9$ & Diğer uzmanlaşmış kirlilik kontrol hizmetleri \\
\hline 24 & $\mathrm{~F}$ & 43.29 & 43.29 .11 & $5,13 \mathrm{~B}$ & İzolasyon işleri \\
\hline 25 & M & 71.12 & 71.12 .15 & 3 & $\begin{array}{l}\text { Mühendislik hizmetleri, atık yönetimi projeleri } \\
\text { için (tehlikeli ve tehlikesiz atıklar) }\end{array}$ \\
\hline 26 & M & 74.90 & 74.90 .13 & $1, \ldots, 16$ & Çevre danışmanlığı hizmetleri \\
\hline
\end{tabular}

\begin{tabular}{|l|l|l|l|}
\hline \multicolumn{3}{|l|}{ Ek 3. \%X ÇMHS Kategorisine Dahil Olan Sektörler } \\
\hline $\begin{array}{l}\text { NACE } \\
\text { Rev.2 }\end{array}$ & $\begin{array}{l}\text { CPA } \\
\text { Kodu }\end{array}$ & $\begin{array}{l}\text { CEPA/ } \\
\text { CReMA }\end{array}$ & CPA Kodlarının Açıklamaları \\
\hline 01 & 01 & 4 & Tarım ve avcılık ürünleri ve ilgili hizmetler \\
\hline 01 & 01.1 & 4 & Tek yıllık (uzun ömürlü olmayan) bitkisel ürünler \\
\hline 01 & 01.2 & 4 & Çok yıllık (uzun ömürlü) bitkisel ürünler \\
\hline 01 & 01.4 & 4 & Canlı hayvanlar ve hayvansal ürünler \\
\hline 01.61 & 01.61 & 4 & Bitkisel üretim için destekleyici hizmetler \\
\hline 01.61 & 01.61 & 10 & Bitkisel üretim için destekleyici hizmetler \\
\hline 02.20 & 02.20 .14 & $13 \mathrm{~A}$ & Yakacak odunlar \\
\hline
\end{tabular}




\begin{tabular}{|c|c|c|c|}
\hline 02.40 & 02.40 & $11 \mathrm{~A}$ & Ormancılık için destekleyici hizmetler \\
\hline 03 & 03.00 .72 & 6,12 & Su ürünleri için destekleyici hizmetler \\
\hline 08.99 & 08.99 .1 & 5 & Bitüm ve asfalt, doğal; asfaltitler ve asfaltlı kayalar \\
\hline 09 & 09 & 3 & Madencilik için destekleyici hizmetler \\
\hline 13.92 & 13.92 .21 & 3 & $\begin{array}{l}\text { Çuval, torba, çanta ve benzerleri (eşya paketleme amacıyla } \\
\text { kullanılanlar) }\end{array}$ \\
\hline 13.96 & 13.96.1 & $13 \mathrm{~A}$ & $\begin{array}{l}\text { Metalize iplikler veya metalize gipe iplikler; metal ipliklerden } \\
\text { dokunmuş kumaşlar ve metalize ipliklerden dokunmuş kumaşlar; } \\
\text { tekstil kaplanmış kauçuk ip ve kordonlar ile teknik kullanım için tekstil } \\
\text { ürünleri ve eşyaları }\end{array}$ \\
\hline 16.10 & 16.10 .22 & 13B & Ağaç yünü; ağaç unu \\
\hline 16.10 & 16.10 .23 & $13 \mathrm{~A}$ & Ağaç talaş ve yongaları \\
\hline 16.23 & 16.23 .11 & 13B & $\begin{array}{l}\text { Pencereler, pencereli kapılar (Fransız penceresi) ve bunların kasaları } \\
\text { ile kapılar ve bunların kasaları ve eşikleri (ahşaptan yapılmış) }\end{array}$ \\
\hline 16.23 & 16.23 .20 & 13B & Prefabrik ahşap yapılar \\
\hline 16.24 & 16.24 & $11 \mathrm{~B}$ & Ahşap konteynerler \\
\hline 16.29 & 16.29 & $13 \mathrm{~A}$ & $\begin{array}{l}\text { Diğer ahşap ürünler; mantar, hasır ve örme malzemesinden (saz, } \\
\text { saman vb.) eşyalar }\end{array}$ \\
\hline 16.29 & 16.29 .2 & $5.13 B$ & $\begin{array}{l}\text { Mantar, hasır veya diğer örme malzemesinden (saz, saman vb.) } \\
\text { eşyalar; sepet türü ve hasır işi eşyalar }\end{array}$ \\
\hline 17 & 17 & 13B & Kağıt ve kağıt ürünleri \\
\hline 19.20 & 19.20.2 & 1 & Petrol türevi yakıtlar; makine yağları (yağlama yağları) \\
\hline 20.14 & 20.14 & $13 \mathrm{~A}$ & Diğer organik temel kimyasallar \\
\hline 20.14 & $20.14 .72^{1}$ & $13 \mathrm{~A}$ & Odun kömürü \\
\hline 20.16 & 20.16 .2 & 13B & Stiren polimerleri, birincil formda \\
\hline 20.16 & 20.16 .56 & 13B & $\begin{array}{l}\text { Diğer amino reçineler, fenolik reçineler ve poliüretanlar, birincil } \\
\text { formda }\end{array}$ \\
\hline 20.3 & 20.3 & $13 C$ & $\begin{array}{l}\text { Boya, vernik ve benzeri kaplayıcı maddeler ile } \\
\text { matbaa mürekkepleri ve macunlar }\end{array}$ \\
\hline 20.41 & 20.41 & $13 C$ & Sabun ve deterjanlar, temizleme ve cilalama ürünleri \\
\hline 20.59 & 20.59 .54 & 2 & Aktif karbonlar \\
\hline 20.59 & 20.59 .59 & $13 \mathrm{~A}$ & Başka yerde sınıflandırılmamış çeşitli diğer kimyasal ürünler \\
\hline 22.21 & 22.21 .2 & 2,10 & Tüp, boru ve hortumlar ile bunların bağlantı elemanları, plastikten \\
\hline 22.22 & 22.22 .11 & 3 & $\begin{array}{l}\text { Torba ve çantalar (koniler dahil, el çantaları hariç), etilen } \\
\text { polimerlerinden }\end{array}$ \\
\hline
\end{tabular}

1 Bu ürün \%100 ÇMHS'lere dahil edilmiştir. 


\begin{tabular}{|c|c|c|c|}
\hline 22.22 & 22.22 .12 & $13 C$ & $\begin{array}{l}\text { Torba ve çantalar (koniler dahil, el çantaları hariç̧), diğer plastiklerden } \\
\text { (etilen polimerlerinden olanlar hariç) }\end{array}$ \\
\hline 22.22 & 22.22 .19 & 3 & $\begin{array}{l}\text { Makara, masura, bobin, tıkaç, kapak, ağ (file) ve taşıma veya } \\
\text { paketlemede kullanılan diğer eşyalar, plastikten" }\end{array}$ \\
\hline 22.23 & 22.23 .13 & 2 & $\begin{array}{l}\text { Depolar, tanklar, fıçılar ve benzeri kaplar, kapasitesi > } 300 \text { litre, } \\
\text { plastikten }\end{array}$ \\
\hline 22.23 & 22.23 .14 & $5,13 \mathrm{~B}$ & $\begin{array}{l}\text { Kapı, pencere ve bunların kasaları ile pervazları ve kapı eşikleri; } \\
\text { panjurlar, storlar, jaluziler ve benzeri eşyalar ile bunların parçaları, } \\
\text { plastikten }\end{array}$ \\
\hline 22.29 & 22.29 .26 & 2 & $\begin{array}{l}\text { Bağlantı parçaları, mobilya, kaporta ve benzerleri için, plastikten; } \\
\text { biblo ve diğer süs eşyaları, plastikten }\end{array}$ \\
\hline 22.29 & 22.29 .29 & 3 & Diğer plastik ürünler \\
\hline 23.12 & 23.12 .13 & 5 & Cam aynalar; çok katlı yalıtım camları \\
\hline 23.14 & $23.14 .1^{2}$ & 13B & Cam elyaf \\
\hline 23.51 & 23.51 .12 & 14 & $\begin{array}{l}\text { Portland çimentosu, alüminli (şaplı) çimento, cüruf çimentosu ve } \\
\text { benzeri hidrolik çimentolar }\end{array}$ \\
\hline 23.61 & 23.61 & 2,10 & Betondan ürünler, inşaat amaçlı \\
\hline 23.61 & 23.61 .12 & $5,13 \mathrm{~B}$ & $\begin{array}{l}\text { Prefabrik yapı elemanları, çimentodan, betondan veya suni taştan } \\
\text { (bina veya bina dışı inşaat işleri için) }\end{array}$ \\
\hline 23.62 & 23.62 .10 & $5,13 B$ & Alçı ürünler, inşaat amaçlı \\
\hline 23.99 & 23.99 & 13B & Başka yerde sınıflandırılmamış metalik olmayan diğer mineral ürünler \\
\hline 23.99 & 23.99.19 & 5 & Başka yerde sınıflandırılmamış metalik olmayan mineral ürünler \\
\hline 24.33 & 24.33 .30 & $5,13 B$ & Sandviç paneller, kaplanmış çelik levhadan \\
\hline 24.51 & 24.51 .20 & 2.10 & Tüpler, borular ve içi boş profiller, dökme demirden \\
\hline 25.12 & 25.12 & 13B & Kapılar ve pencereler, metalden \\
\hline 25.21 & 25.21 .12 & 13B & $\begin{array}{l}\text { Merkezi ısıtma kazanları (boyler), sıcak su veya alçak basınçlı buhar } \\
\text { üretmek için (kombiler dahil) }\end{array}$ \\
\hline 25.21 & 25.21 .13 & 13B & Merkezi ısıtma kazanlarının (boyler) ve kombilerin parçaları \\
\hline 25.29 & 25.29 & 3 & Diğer tanklar, rezervuarlar ve konteynerler (metalden) \\
\hline 25.92 & 25.92 & 3 & Hafif metalden paketleme malzemesi \\
\hline 25.99 & 25.99 & 3,7 & Başka yerde sınıflandırılmamış diğer fabrikasyon metal ürünler \\
\hline 25.99 & 25.99 .29 & 2 & Başka yerde sınıflandırılmamış adi metalden diğer ürünler \\
\hline 26.11 & 26.11 .22 & $11 \mathrm{~A}$ & $\begin{array}{l}\text { Yarı iletken aygıtlar; ışık yayan diyotlar (LED); monte edilmiş piezo } \\
\text { elektrik kristalleri; bunların parçaları }\end{array}$ \\
\hline
\end{tabular}




\begin{tabular}{|c|c|c|c|}
\hline 26.11 & 26.11 .40 & $11 \mathrm{~A}$ & $\begin{array}{l}\text { Başka yerde sınıflandırılmamış elektronik valflerin ve tüplerin } \\
\text { parçaları ile diğer elektronik bileşenlerin parçaları }\end{array}$ \\
\hline 26.51 & 26.51 .53 & 1,2 & $\begin{array}{l}\text { Fiziksel veya kimyasal analizler için başka yerde sınıflandırılmamış } \\
\text { alet ve cihazlar }\end{array}$ \\
\hline 26.51 & 26.51 .70 & 13B & $\begin{array}{l}\text { Termostatlar, monostatlar ve diğer otomatik ayar veya } \\
\text { kontrol alet ve cihazları }\end{array}$ \\
\hline \multirow[t]{2}{*}{27.40} & 27.40 .15 & $13 \mathrm{~B}$ & Deşarj lambaları; morötesi veya kızılötesi lambalar; ark lambaları \\
\hline & 27.5 & $13 B$ & Ev aletleri \\
\hline 27.52 & 27.52 .12 & $13 \mathrm{~A}$ & $\begin{array}{l}\text { Diğer ev cihazları, gaz yakıtı veya hem gaz hem de diğer yakıtlı, sıvı } \\
\text { veya katı yakıtlı }\end{array}$ \\
\hline 27.52 & 27.52 .14 & $13 \mathrm{~A}$ & Su ısıtıcıları, anında veya depolu, elektriksiz \\
\hline 28.13 & 28.13 & 2 & Diğer pompa ve kompresörler \\
\hline 28.14 & 28.14 .11 & $13 B$ & Basınç düşürme, kontrol, test ve güvenlik valfleri \\
\hline 28.14 & 28.14 .12 & 13B & $\begin{array}{l}\text { Musluk, tıkaç ve valfler (eviye, lavabo, klozet, küvet ve benzeri sabit } \\
\text { eşyalar için); merkezi ısıtma radyatör valfleri }\end{array}$ \\
\hline 28.14 & 28.14 .13 & $13 B$ & İşlem kontrol valfleri, sürgülü valfler, glob valfler ve diğer valfler \\
\hline 28.21 & 28.21 .12 & 3 & $\begin{array}{l}\text { Sanayi ve laboratuvar ocak ve fırınları (elektriksiz), çöp yakma } \\
\text { fırınları dahil, fakat Ekmek ve unlu mamul fırınları hariç }\end{array}$ \\
\hline 28.25 & 28.25 .13 & $13 B$ & Soğutma ve dondurma ekipmanları ve ısıtma pompaları \\
\hline 28.25 & 28.25 .14 & 1 & $\begin{array}{l}\text { Başka yerde sınıflandırılmamış makine ve cihazlar, gazların } \\
\text { filtrelenmesi ve arıtılması }\end{array}$ \\
\hline 28.25 & 28.25 .30 & - & $\begin{array}{l}\text { Soğutucu ve dondurucu ekipmanların ve ısıtma pompalarının } \\
\text { parçaları }\end{array}$ \\
\hline 28.29 & 28.29 .12 & 2 & Filtreleme veya arıtma makineleri ve cihazları, sıvılar için \\
\hline 28.29 & 28.29 .82 & 1 & $\begin{array}{l}\text { Santrifüjlerin parçaları; sıvı veya gazlar için filtreleme veya arıtma } \\
\text { makine ve Cihazlarının parçaları }\end{array}$ \\
\hline 28.41 & 28.41 & 14 & Metal işleme makineleri \\
\hline \multirow[t]{2}{*}{28.92} & 28.92 & 3 & Maden, taşocağı ve inşaat makineleri \\
\hline & 29 & 1 & Motorlu kara taşıtları, treyler (römork) ve yarı treyler (yarı römork) \\
\hline 29.10 & 29.10 .59 & 2,3 & Başka yerde sınıflandırılmamış özel amaçlı motorlu kara taşıtları \\
\hline \multirow[t]{3}{*}{29.32} & 29.32 .30 & 1 & $\begin{array}{l}\text { Motorlu kara taşıtları için başka yerde sınıflandırılmamış parça ve } \\
\text { aksesuarlar }\end{array}$ \\
\hline & 30 & 1 & Diğer ulaşım araçları \\
\hline & 33.1 & Tümü & $\begin{array}{l}\text { Fabrikasyon metal ürünlerin, makinelerin ve ekipmanların onarım } \\
\text { hizmetleri }\end{array}$ \\
\hline 33.12 & 33.12 .12 & 10 & $\begin{array}{l}\text { Akışkan gücü ile çalışan ekipmanların, diğer pompaların, } \\
\text { kompresörlerin, muslukların ve valflerin bakım ve onarım hizmetleri }\end{array}$ \\
\hline
\end{tabular}




\begin{tabular}{|c|c|c|c|}
\hline 33.2 & 33.2 & Tümü & Sanayi makinelerinin ve ekipmanlarının kurulum hizmetleri \\
\hline 35.11 & 35.11 .10 & $13 \mathrm{~A}$ & Elektrik enerjisi \\
\hline 35.2 & 35.2 & 1 & Mamul gaz; şebeke üzerinden gaz yakıtların dağıtımı hizmetleri \\
\hline 35.2 & 35.2 & $13 \mathrm{~A}$ & Mamul gaz; şebeke üzerinden gaz yakıtların dağıtımı hizmetleri \\
\hline 35.3 & 35.3 & $13 \mathrm{~A}$ & Buhar ve iklimlendirme temin hizmetleri \\
\hline 36.00 & 36.00 .1 & 10 & Doğal su \\
\hline 36.00 & 36.00 .2 & 10 & Suyun arıtılması ve şebeke üzerinden dağıtım hizmetleri \\
\hline 38.22 & 38.22 .2 & 7 & Nükleer ve diğer tehlikeli atıkların bertaraf hizmetleri \\
\hline 38.22 & 38.22 .21 & 7 & Nükleer atıkların bertaraf hizmetleri \\
\hline 39.00 & 39.00 .2 & $1, \ldots, 9$ & Diğer iyileştirme ve uzmanlaşmış kirlilik kontrol hizmetleri \\
\hline 41.00 & 41.00 .10 & 13B & İkamet amaçlı binalar \\
\hline 41.00 & 41.00 .2 & 13B & İkamet amaçlı olmayan binalar \\
\hline 42.21 & 42.21 .1 & 10 & Akışkanlar için hizmet projeleri \\
\hline 42.21 & 42.21 .23 & 2 & $\begin{array}{l}\text { Sulama sistemleri (kanallar), ana su şebekeleri ve su hatları, su } \\
\text { arıtma tesisleri, kanalizasyon bertaraf tesisleri ve pompa istasyonları } \\
\text { için inşaat işleri }\end{array}$ \\
\hline 42.21 & 42.21 .24 & 2 & Su kuyusu açma ve septik sistem kurulum işleri \\
\hline 42.22 & 42.22 .23 & 13B & Güç santralleri için inşaat işleri \\
\hline 43.21 & 43.21 .10 & $13 \mathrm{~A}$ & Elektrik tesisatı işleri \\
\hline 43.22 & 43.22 .12 & 13B & Isıtma, havalandırma ve iklimlendirme tesisatı işleri \\
\hline 43.99 & 43.99 & 3 & Başka yerde sınıflandırılmamış diğer uzmanlaşmış inşaat işleri \\
\hline 43.99 & 43.99 & 5 & Başka yerde sınıflandırılmamış diğer uzmanlaşmış inşaat işleri \\
\hline 43.99 & 43.99 .7 & 13B & Prefabrik yapıların montajı ve kurulması işleri \\
\hline 71.12 & 71.12 .12 & 13B & Mühendislik hizmetleri, bina projeleri için \\
\hline 71.12 & 71.12 .13 & $13 \mathrm{~A}$ & Mühendislik hizmetleri, enerji projeleri için \\
\hline 71.12 & 71.12 .16 & $2,4,10$ & Mühendislik hizmetleri (su, kanalizasyon ve drenaj projeleri için) \\
\hline 71.20 & 71.20 .14 & 1 & Kara yolu taşıma araçlarının teknik muayene hizmetleri \\
\hline 72.1 & 72.1 & 8,15 & $\begin{array}{l}\text { Araştırma ve deneysel geliştirme hizmetleri, doğal bilimler ve } \\
\text { mühendislik konularında }\end{array}$ \\
\hline 81.29 & 81.29 .12 & 3 & Süpürme ve kar temizleme hizmetleri \\
\hline 84.1 & 84.1 & Tümü & $\begin{array}{l}\text { Ülke yönetimi ve toplumun ekonomik ve sosyal politikalarının } \\
\text { yönetimi }\end{array}$ \\
\hline 94.99 & 94.99 & Tümü & $\begin{array}{l}\text { Başka yerde sınıflandırılmamış diğer üyelik kuruluşları tarafından } \\
\text { verilen hizmetler }\end{array}$ \\
\hline
\end{tabular}

